\title{
Is Uber a substitute or complement for public transit?*
}

\author{
Jonathan D. Hall \\ University of Toronto \\ Craig Palsson \\ Utah State University \\ Joseph Price \\ Brigham Young University and NBER
}

October 16, 2018

\begin{abstract}
How Uber affects public transit ridership is a relevant policy question facing cities worldwide. Theoretically, Uber's effect on transit is ambiguous: while Uber is an alternative mode of travel, it can also increase the reach and flexibility of public transit's fixed-route, fixed-schedule service. We estimate the effect of Uber on public transit ridership using a difference-in-differences design that exploits variation across U.S. metropolitan areas in both the intensity of Uber penetration and the timing of Uber entry. We find that Uber is a complement for the average transit agency, increasing ridership by five percent after two years. This average effect masks considerable heterogeneity, with Uber increasing ridership more in larger cities and for smaller transit agencies.
\end{abstract}

*We are grateful for helpful feedback from Jonathan V. Hall, who works for Uber and should not be confused with one of the authors of this paper, Will Strange, Rob McMillan, Peter Morrow, Morley Gunderson, Jessica Peck, and seminar audiences at the University of Toronto, Washington University in St. Louis, ETH Zurich, University of Southern California, Cal State-Long Beach, International Transport Economics Association, University of Toronto/University of British Columbia Summer Conference, Urban Economics Association, and the Canadian Political Science Association. This research was supported by the Social Sciences and Humanities Research Council of Canada. We received excellent research assistance from Michael Gmeiner, Matthew Walshe, Marc-Antoine Schmidt, Tanner Eastmond, and Mona Balesh Abadi. The authors declare that they have no relevant or material financial interests that relate to the research described in this paper.

(c)2018. This manuscript version is made available under the CC-BY-NC-ND 4.0 license http://creativecommons.org/licenses/by-nc-nd/4.0/. The published version of this paper can be found at https://doi.org/10.1016/j.jue.2018.09.003. 


\section{Introduction}

Uber, Lyft, and other ride-hailing companies have transformed the transportation marketplace in over six hundred cities around the world. While their entry into cities has been controversial, they have been credited with providing a reliable and affordable transportation option, serving neglected areas of cities, and providing meaningful employment. Against these benefits, they have been accused of being unsafe, creating congestion, destroying stable jobs, and flouting the law. Governments have struggled to decide how to regulate these companies, in part because of a poor understanding of the actual economic effects of ride-hailing companies.

Economists are quickly trying to understand Uber's general economic effects and especially its influence on other modes of transportation. Uber's direct benefits appear to be large. Using Uber's individual-level data and its unique use of surge pricing, Cohen et al. (2016) estimate that UberX created $\$ 6.8$ billion of consumer surplus in 2015. The indirect effects are less clear: recent evidence shows that Uber could benefit public health by reducing drunk driving accidents and fatalities (Greenwood and Wattal 2017; Peck 2017; Dills and Mulholland 2018), though other research finds no effect on traffic fatalities (Brazil and Kirk 2016). In terms of the effect on other modes of transportation, Nie (2017) finds Uber has reduced taxi ridership, though its effect on taxi driver wages is less clear (Cramer 2016; Berger et al. 2018).

This paper's contribution is to measure the effect of Uber on public transit. There are three reasons Uber's effect on public transit is important, and all three depend on whether Uber complements public transit. First, Uber could have important effects on public transit's social efficiency. Transit fares are typically above social marginal cost (though below average cost) due to economies of scale and density, implying transit ridership is inefficiently low. ${ }^{1}$ If Uber increases transit ridership this would then increase the efficiency of the public-transit system. Second, Uber's effect on public transit directly affects city and state budgets. Ridehailing services already face fierce political opposition from taxi services, and its effect on government budgets could tip the political balance. ${ }^{2}$ Third, the interaction

\footnotetext{
${ }^{1}$ Proost and Dender (2008), Parry and Small (2009), and Basso and Silva (2014) show that increasing transit subsidies, and so increasing transit ridership, increases social welfare given the existing set of transportation policies.

${ }^{2}$ See Spicer and Eidelman (2017) for a review of the political opposition to Uber.
} 
between Uber and public transit affects congestion and pollution. ${ }^{3}$ Regardless of whether Uber is a complement or substitute for public transit, Uber can increase congestion and pollution simply by increasing the number of trips taken. However, its effect on congestion and pollution will be larger if it is a net substitute for transit.

Uber could affect public transit through two mechanisms. On the one hand, Uber is an alternative mode of travel, and riders might leave public transit for the new mode. On the other hand, riders could use Uber to overcome the last mile problem caused by public transit's fixed-route, fixed-schedule service. Support for both mechanisms can be found from trends in public transit use. In favor of substitution, ridership has declined for many public transit providers in the U.S., and pundits have speculated Uber could be the cause. ${ }^{4}$ In favor of Uber's role as complement, when the London Underground extended its service hours, Uber ridership during those hours increased. ${ }^{5}$

Uber data and surveys on ride-hailing use show clear correlations between Uber and public transit use, but such data have not concluded what the causal effect of Uber is on public transit. First, in several cities, 25-40 percent of all Uber pick-ups and drop-offs are near a public transit station; however, Uber acknowledges that it is impossible to tell whether someone is using Uber to get to a transit stop or to get to a destination that happens to be near a transit stop (Smith 2015). Second, a Pew (2016) survey found that public transit use is highly correlated with Uber use, with 9 percent of those who do not use Uber at all taking public transit each week and 56 percent of those who use Uber weekly taking public transit each week. Third, Murphy and Feigon (2016) found that 15 percent of those who use ride-hailing apps, car-sharing, or bike-sharing report that they ride public transit

\footnotetext{
${ }^{3}$ See Anderson (2014) and Adler and van Ommeren (2016) for evidence that public transit reduces congestion, and Gendron-Carrier et al. (2018) for evidence that public transit reduces air pollution.

${ }^{4}$ For example, see Fitzsimmons, Emma. 2017. "Subway Ridership Declines in New York. Is Uber to Blame?" New York Times. 24 February 2017; Nelson, Laura and Dan Weikel. 2016. "Billions spent, but fewer people are using public transportation in Southern California." Los Angeles Times. 27 January 2016; Curry, Bill. 2016. "Where have all the transit riders gone." The Globe and Mail. 27 May 2016; or Lazo, Luz. 2016. "Ripple effect of Metro's troubles: plummeting bus ridership across the region." The Washington Post. 20 February 2016.

5"London's new late night alternative: The Night Tube + Uber." 7 October 2016. Accessed 9 October 2017. https://medium.com/uber-under-the-hood/ londons-new-late-night-alternative-the-night-tube-uber-8f38e56de983.
} 
more but Rayle et al. (2016) found that 33 percent of those using a ride-hailing app in San Francisco said their next best alternative for their current trip was using public transit. Thus, while the evidence suggests there is a relationship, nothing has provided a clear picture of the net effect.

We estimate Uber's net effect on public transit using a difference-in-differences approach across all Metropolitan Statistical Areas (MSAs) in the United States with public transit. We exploit two sources of variation across MSAs. The first is variation in when Uber entered each market, and the second is variation in the intensity of Uber penetration, as measured using the relative number of Google searches for "Uber" in each MSA. This measure is strongly correlated with the number of Uber drivers per capita in each market (Cramer 2016).

A major threat to identification is whether Uber chooses to enter based on something correlated with transit ridership. We address this concern in four ways. First, we discussed this issue with executives at Uber and they stated that the formal process for deciding where to enter did not include a discussion of public transit. Second, confirming their statement, regression analysis shows Uber largely entered MSAs in population rank order. Third, our main regressions allow each MSA to have its own linear time trend, and fourth, a test similar to Autor (2003) shows there are no pre-trends in transit ridership related to when Uber enters a MSA.

Using public transit data from the National Transit Database, we find that for the typical transit agency Uber complements public transit, with a one standard deviation increase in Uber penetration leading to a $1.38 \%$ increase in transit ridership. Uber's effect on transit ridership grows slowly over time, increasing transit ridership by $5 \%$ after two years. However, this average effect masks considerable heterogeneity in Uber's effect on public transit. Uber is more of a complement in larger cities and for transit agencies with lower ridership prior to Uber's existence, and Uber penetration is higher in the same places. Comparing the effect across modes, Uber's effect on bus ridership follows the same pattern of increasing average ridership, having a larger effect on larger cities and for smaller bus agencies; in contrast, Uber is more of a complement for larger rail agencies. We also find suggestive evidence that Uber is reducing commute times for those riding public transit, while increasing traffic congestion.

This paper is a continuation of the the literature on how new transportation 
technologies affect cities. For example, LeRoy and Sonstelie (1983) show how the invention of the automobile changed where rich and poor live within cities, and Baum-Snow (2007) shows how the construction of limited access highways lead to suburbanization. This paper provides the first estimates of how ride-hailing is affecting cities, via its effect on public transportation.

Our results also speak to the literature on factors affecting transit use. BaumSnow and Kahn (2000) show that public investments in transit leads to more transit ridership; our findings are consistent with theirs but we show that increased ridership can come from private investment. Uber, however, does reduce transit ridership in some cities, consistent with Goetzke (2008), who find that transit usage is decreasing in car access.

\section{Why Uber could be either a complement or substi- tute for public transit}

Our goal is to measure the net impact of Uber on public transit, to establish whether it is a net substitute or a net complement for public transit.

It is easy to make a case that Uber could take riders away from public transit: Uber increases the convenience and reduces the cost of taking a taxi-like service. Greenwood and Wattal (2017) show that UberX provides a 20 to 30 percent reduction in prices relative to traditional taxis. Uber is also typically more convenient as a ride can be hailed easily through a smartphone application and provides real-time information on the estimated arrival time. While Uber fares are typically higher than public transit fares, riders will substitute Uber for public transit if Uber is fast enough and convenient enough to outweigh its additional cost.

The case for Uber complementing public transit comes from the fact that most public transit systems use fixed routes with fixed schedules. It is Uber's ability to fill in the holes in public transit coverage, substituting for particularly bad transit trips, that allows Uber to complement transit overall. There are at least two mechanisms by which this can happen.

First, Uber makes it cheaper and easier to travel to places, and at times, that

public transit serves poorly. As a result, the combination of public transit and Uber can make it possible to complete all desired trips without owning a car, or 
for families to own just one car. In addition, the first and last portions of a trip on public transit typically account for a small share of the distance traveled but a large share of the travel time; by substituting for this portion of a trip, Uber can lower the cost of using transit for the main portion of the trip. This can especially make traveling by train more appealing. As another example, people might take transit to an evening activity and then, because transit service is less frequent late at night, take Uber home.

Second, Uber helps deal with the risks of relying on fixed-schedule public transit. Some people might be happy to use public transit if it provided the same flexibility as driving but choose not to do so because the schedule cannot respond to personal emergencies or changes in work schedules. The ability to use Uber if you need to get home because a child is sick or do not want to wait for the bus in the rain could make riding public transit more appealing, increasing transit ridership.

It is also possible that Uber does not affect individuals' transit use. Tautologically, Uber will not affect public transit if none of its riders used public transit. It may be the case that public transit riders, knowing they need to rely on public transit, have already chosen work, shopping, and living arrangements subject to their transit constraints. If Uber does not provide a greater benefit than public transit, or if Uber's benefit does not justify the cost, then we will not observe a change. Even if Uber does provide a benefit, research has shown that commuters do not experiment with travel patterns and overlook more efficient routes unless forced to try them (Larcom et al. 2017).

At the individual level, there is evidence for all of the above effects. The goal of this paper is to determine the net effect, and as the strength of these mechanisms differs for different types of trips, we expect to find that Uber has heterogeneous effects on transit. In particular, Uber is likely to have a stronger effect, either positive or negative, in larger cities where transit riders tend to be wealthier and thus able to pay Uber fares. ${ }^{6}$ In addition, smaller transit agencies will tend to have less complete coverage in terms of both geographic coverage and frequency. This could mean that their service is so poor that Uber will be a strong substitute, or

\footnotetext{
${ }^{6}$ In smaller cities a greater share of transit riders are those who cannot afford to drive. These "captive riders" are unlikely to switch to Uber. We find that the correlation between the median income of transit riders and MSA population is 0.234 in the 2011-2015 American Community Survey 5-year estimates.
} 
that Uber's ability to fill holes in their coverage is all the more valuable so that Uber will be a strong complement.

\section{Data}

To estimate the effect of Uber on public transit, we collect data on transit ridership, Uber entry and exit, and a variety of controls for 2004-2015. Our unit of observation is a transit agency, and the average Metropolitan Statistical Area with public transit contains 2.21 transit agencies.

Our data on transit ridership come from the National Transit Database (NTD). This database contains monthly ridership for essentially all transit agencies which receive federal funding and reports ridership separately by mode (bus, train, etc.). ${ }^{7}$ Specifically, they report the number of times a rider steps onto a transit vehicle, and so a trip that uses multiple transit vehicles counts as multiple rides. In 2015, the National Transit Database captured 98\% of the total number of trips that the American Public Transit Association estimates happened in the country and over $99 \%$ of those trips that happened on a bus or train (2018). ${ }^{8}$ The National Transit Database also contains data on important supply-side variables: fares, capital expenditures, maximum number of vehicles in service, the number of vehicle-hours of service, and the number of vehicle-miles of service.

We gathered information for each MSA on when each Uber service entered, and exited. ${ }^{9}$ Our sample includes 196 MSAs where Uber has had a presence. Entry and exit were determined based on newspaper articles as well as Uber's press releases, blog posts, and social media posts.

We proxy for Uber penetration rates using data from Google Trends on the share of Google searches for "Uber" at the MSA level, an approach similar to

\footnotetext{
${ }^{7}$ Any agency receiving funds from a Federal Transit Administration (FTA) formula program must submit reports to the NTD. Such programs account for seventy percent of all FTA funding. To the best of our knowledge, the only other source of federal funding for public transit is Department of Homeland Security funding for security improvements. Transit systems with no trains and no more than 30 vehicles in operation at any time are not required to report monthly ridership.

${ }^{8}$ Breaking this down by mode, the gap is largest for demand response (typically transit for the disabled) $(25 \%)$ and ferries (15\%), while for commuter rail and buses, the gap is less than $1 \%$, and for subways, light rail, and streetcars the NTD captures all trips.

${ }^{9}$ We use the 2009 definitions of MSAs throughout this paper.
} 
Cramer (2016). ${ }^{10}$ Because Google Trends normalizes their data so the largest observation in any dataset is 100, and because it is only possible to download data for a few MSAs at a time, each time we download data we include San Francisco. We then normalize each downloaded data set by the search index in San Francisco the week starting January 29th, 2017, and multiply by 100. For our regressions we then convert our measure of search intensity into standard deviation units.

In order to validate our Uber penetration measure, we were able to obtain data from Uber for 16 MSAs similar to that used by Hall and Krueger (2018). We find that Google searches for "Uber" are strongly correlated with the number of active drivers per capita in each market; with an estimated correlation coefficient (when measured in logs) of $0.948 .{ }^{11}$ To address the concern that this correlation is spurious due to a common time trend, we calculate the correlation between the change in the log the number of active drivers per capita and change in the log in the Google Trends search index; we find this correlation is 0.292. Figure 1 plots the number of drivers per 10,000 residents and the Google Trends search index for the 16 cities we have both sets of data for, showing visually how strongly these are correlated. Google Trends data was available for 147 of the 196 MSAs Uber entered during our sample. For this reason, the sample size for some of our analysis on Uber penetration is smaller than the sample based on entry.

We also replicate our results using the number of active Uber drivers per capita, measured in standard deviation units, in Table A.1. Due to the small sample size, these results are not always statistically significant, however, the point estimates are similar to what we find using the Google Trends data, as well as with the Google Trends data limited to the 16 cities for which we have data on the number of active drivers.

We also use data from a variety of sources as additional controls. In regressions predicting Uber's entry decision we use data on MSA population, income, age, and education from the 2008-2012 American Community Survey 5-year estimates. In our main regressions estimating the effect of Uber we use data on monthly MSA total employment and unemployment rates from the Bureau of Labor Statistics, annual MSA population estimates from the U.S. Census Bureau, and monthly

\footnotetext{
${ }^{10}$ Other papers to use Google Trends data include Stephens-Davidowitz (2014), who use it to proxy for racial animus and Hoopes et al. (2015), who use it to measure searches for information about taxes.

${ }^{11}$ A driver is active if they complete at least four trips in a given month.
} 

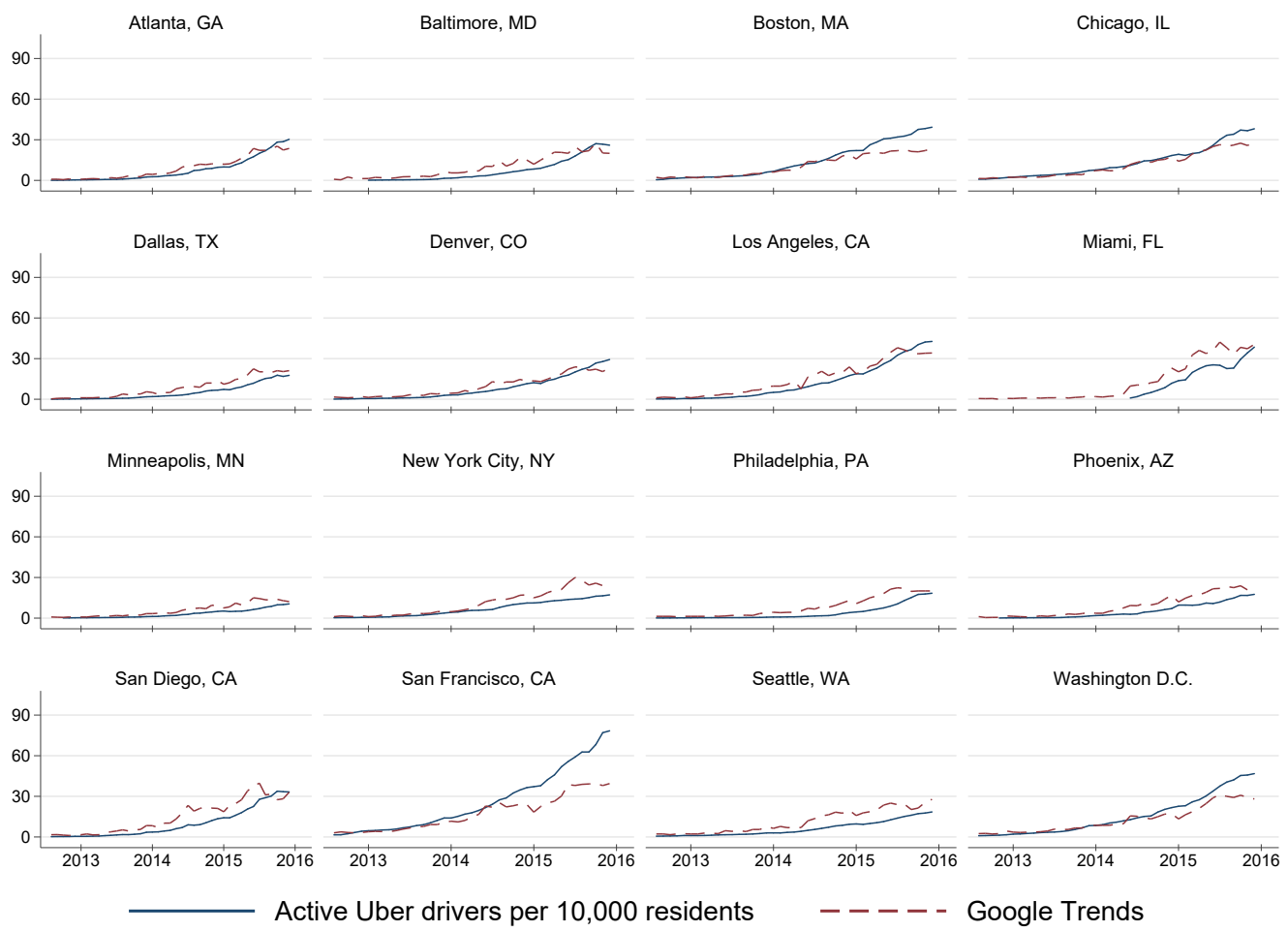

Figure 1: Relative frequency of Google searches for "Uber" compared to number of active Uber drivers per 10,000 residents

Notes: Google Trends search index normalized so it is 100 in San Francisco the week starting January 29th, 2017 (not shown). Data on active drivers provided by Uber. A driver is active if they complete at least four trips in a given month. Annual MSA population estimates from the U.S. Census Bureau. 
Table 1: Summary statistics

\begin{tabular}{lccc}
\hline & Mean & Median & Std. dev. \\
\hline \multicolumn{4}{c}{ Panel A: Transit agency summary statistics } \\
Average bus fare & 1.31 & 0.75 & 4.45 \\
Average rail fare & 4.94 & 2.00 & 11.0 \\
Average fare & 1.77 & 0.91 & 4.13 \\
Maximum bus vehicles operating & 108.1 & 30 & 283.8 \\
Maximum rail vehicles operating & 274.5 & 51 & 725.3 \\
Maximum vehicles operating & 185.2 & 48 & 590.1 \\
Bus vehicle revenue hours (1,000) & 27.8 & 6.90 & 79.1 \\
Rail vehicle revenue hours (1,000) & 76.5 & 11.9 & 231.2 \\
Vehicle revenue hours (1,000) & 40.4 & 8.70 & 158.9 \\
Bus vehicle revenue miles (1,000) & 345.6 & 100.4 & 813.7 \\
Rail vehicle revenue miles (1,000) & 1672.0 & 231.1 & 4556.6 \\
Vehicle revenue miles (1,000) & 616.5 & 135.2 & 2326.7 \\
Bus ridership (100,000) & 9.53 & 1.32 & 41.3 \\
Rail ridership (100,000) & 63.5 & 7.90 & 263.8 \\
Total ridership (100,000) & 15.6 & 1.21 & 124.7 \\
\hline Observations & 76,213 \\
\hline \multicolumn{4}{c}{ Panel B: MSA summary statistics } \\
Population (100,000) & 8.74 & 3.45 & 17.9 \\
Employment (100,000) & 4.12 & 1.57 & 8.39 \\
Gas price & 2.94 & 2.91 & 0.65 \\
Google search intensity for “Uber” & 2.08 & 0.75 & 3.79 \\
Uber in MSA & 0.075 & 0 & 0.26 \\
\hline Observations & 40,012 \\
\hline & \multicolumn{3}{c}{} \\
\hline
\end{tabular}

Notes: The summary statistics in Panel A are averages of monthly observations from 2004-2015 for all transit agencies in the NTD. Those in Panel B are averages of monthly observations for each MSA. See text for Panel B's data sources. Transit ridership measures the number of times someone steps onto a transit vehicle, and so a trip that uses multiple transit vehicles counts as multiple rides. 


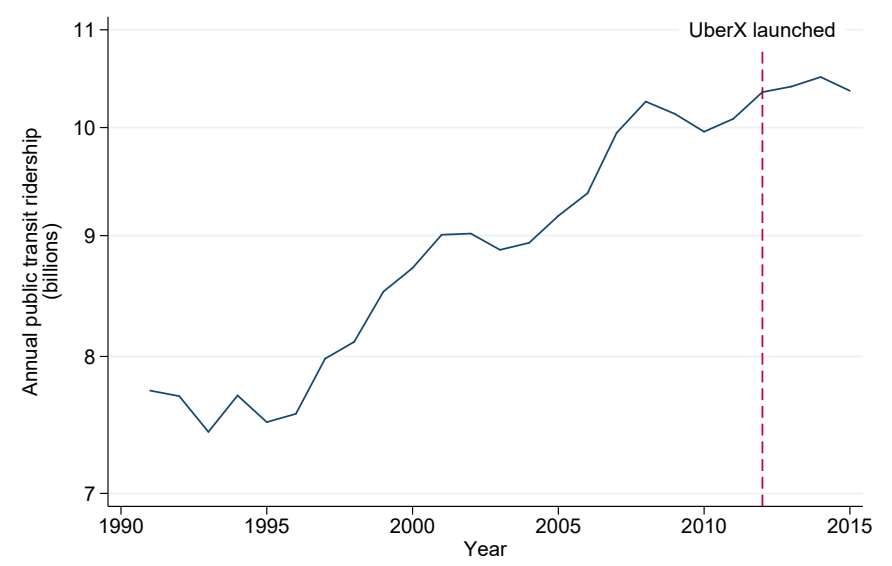

Figure 2: National transit ridership over time: 1991-2015

Notes: National transit ridership measured from the National Transit Database. Transit ridership measures the number of times someone steps onto a transit vehicle, and so a trip that uses multiple transit vehicles counts as multiple rides.

regional gas prices from the U.S. Energy Information Administration.

Table 1 reports the summary statistics for our sample, and Figure 2 plots the national trends in transit ridership from 1991-2015. Note that Figure 2 clearly shows the effects of the 2007-2009 recession, as well as a recent decline which has led to speculation on whether Uber has decreased transit ridership. The left side of Figure 3 plots the relationship between population and total transit ridership for each MSA, and shows that larger cities have more transit ridership than smaller cities, and that transit ridership climbs faster than population, with a $10 \%$ increase in population leading to a $15.5 \%$ increase in total ridership. The right side of Figure 3 plots the relationship between MSA population and transit ridership for individual transit agencies, showing that within an MSA there is large variation in the size of transit agencies.

\section{Method}

We estimate the effect of Uber on public transit ridership using a difference-indifferences approach. We compare how transit ridership changes in cities when Uber enters relative to changes in cities where Uber has not entered yet. While Uber offers several services, including a black car service, we focus on the entry of 


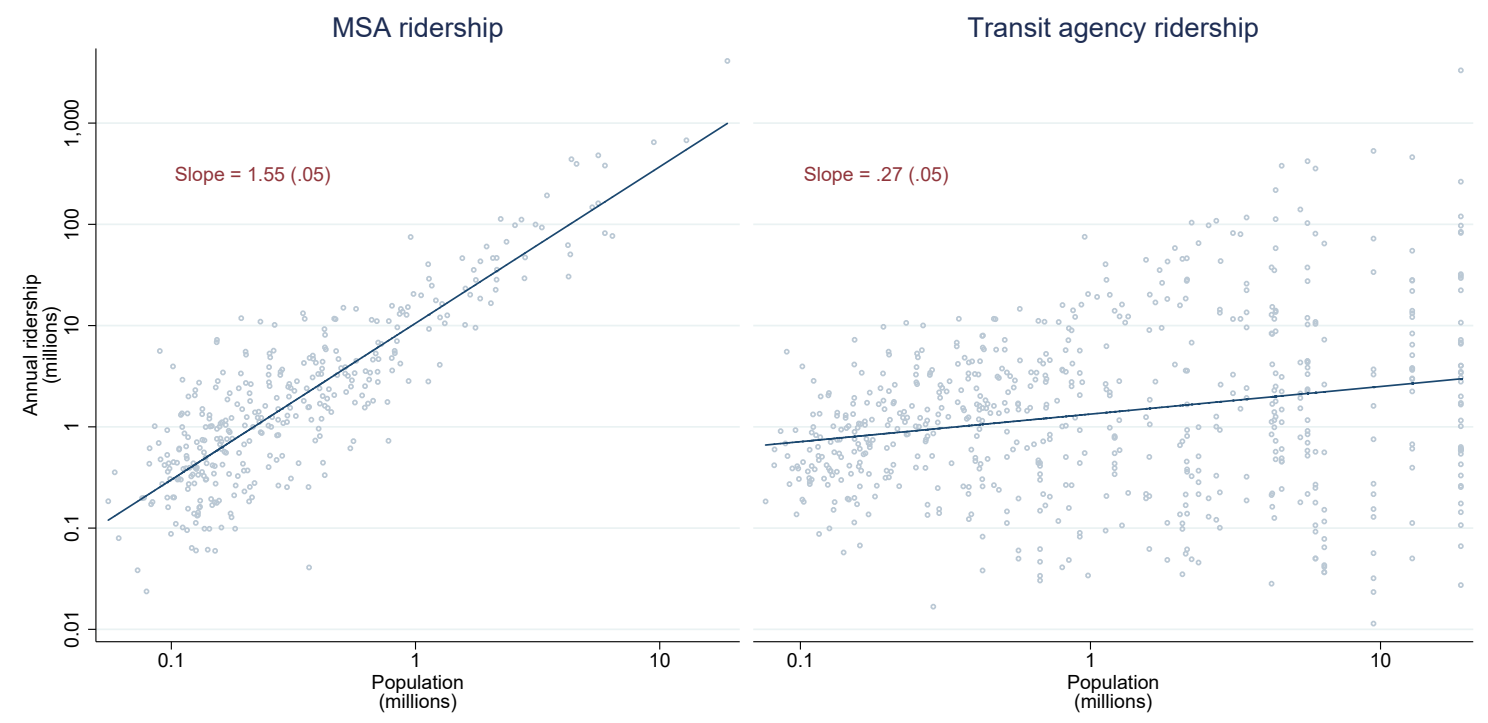

Figure 3: Annual public transit ridership vs. MSA population at the MSA level (left) and transit agency level (right)

Notes: National transit ridership measured from the National Transit Database. Transit ridership measures the number of times someone steps onto a transit vehicle, and so a trip that uses multiple transit vehicles counts as multiple rides. Regression lines and coefficients from regressing $\log$ (ridership) on $\log$ (population). 
UberX, which accounts for the vast majority of their ridership.

Our estimates are based on the following regression:

$$
Y_{i, t}=\beta D_{c(i), t}+\gamma_{i}+\delta_{t}+\theta_{i, m(t)}+\zeta_{c(i)} \cdot t+\boldsymbol{X}_{i, t}^{\prime} \boldsymbol{\eta}+\epsilon_{i, t}
$$

where $Y_{i t}$ is $\log$ transit ridership on transit agency $i$ in year-month $t ; D_{c(i) t}$ is 1 if UberX is active in the MSA $c(i)$ in year-month $t$ and 0 otherwise; $\gamma_{i}$ is a transit agency specific fixed effect; $\delta_{t}$ is a year-month specific fixed effect; $\theta_{i, m(t)}$ is a transit agency-calendar month fixed effect included to address seasonality in transit ridership; ${ }^{12} \zeta_{c(i)}$ is an MSA specific time trend; and $\mathbf{x}_{i t}^{\prime}$ is a vector of controls for transit agency $i$, such as MSA population and total employment, measures of the quantity of service the transit agency provides, and average fares, in year-month $t$. These controls are all factors which affect transit ridership, however, it is also possible that they are changing endogenously in response to Uber's entry. If this were the case, including them biases our estimates. ${ }^{13}$ To address this concern, in Panel B of Table A.2 we show our results are robust to leaving out these controls. To address the serial correlation in the outcomes, we follow the recommendation of Bertrand et al. (2004) to cluster the standard errors, and do so at the MSA level.

We also estimate a version of this same empirical model based on the level of penetration of Uber. We use the same empirical framework as before, but now $D_{c(i) t}$ is the standardized Google Trends search index in MSA $c(i)$. This second measure allows us to exploit variation within the set of treated cities in their intensity of treatment. This captures Uber's market penetration across all their services.

Choosing between the Uber entry-dates and the Google Trends treatments is a trade-off between interpretation and precision. The Uber entry-dates have a clear interpretation: accounting for each city's history and national trends, Uber's entry changed transit ridership by $\beta$. But the gain in clarity sacrifices precision because it treats Uber's entry to New York, NY the same as it does Pocatello, ID. The Google Trends data creates better precision because it allows treatment intensity

\footnotetext{
${ }^{12}$ We omit the transit agency-calendar month fixed effect for January to avoid perfect collinearity between the transit agency-calendar month fixed effects and the transit agency fixed effect.

${ }^{13}$ For example, if transit agencies respond to Uber by reducing transit service, which then reduces transit ridership, then controlling for the amount of transit service will cause our estimates to miss out on this causal channel by which Uber affects transit ridership.
} 
to vary across cities but the interpretation is murkier because the frequency of searches for "Uber" is an equilibrium outcome rather than a measure of exogenous differences in supply. While neither treatment measure is perfect, together they provide insight into the effect of Uber on public transit.

Because we are using difference-in-differences with MSA-specific time trends, the key identifying assumption is that of parallel growth in treated and untreated cities. Thus we are assuming that transit ridership for agencies in San Francisco would have grown above trend by the same percentage as agencies in New York City, except for the presence of Uber (and conditional on controls). Fundamental differences between cities that only effect the level or growth rate of their agencies' transit ridership, such as the built environment or weather, are adjusted for by the fixed effects and time trends. Threats to identification instead come from factors that vary over time at the MSA or transit agency level, covered in the next section.

\section{Estimating Uber's entry decision}

The greatest threat to identification comes from whether Uber chooses to enter based on something that is correlated with transit ridership. Uber executives told us that the official expansion process did not consider public transportation, nor were they in any meetings that discussed public transportation when deciding where to enter. They reported that Uber's goal was to cover as much of the nation (and world) as soon as possible. While this does not mean Uber's entry decision is not driven by a third factor which is itself correlated with transit ridership, it is reassuring. To more fully address this issue, we estimate how Uber decides when and where to enter, concluding Uber largely entered markets based on population, working from large to small.

Figure 4 shows when Uber first entered each MSA, and Figure 5 shows Uber was introduced to cities essentially in population rank order. Kendall's rank correlation between population and entry date is -.37 and for any two MSAs Uber has entered, the probability Uber was available in the larger MSA first is 68 percent.

The first column in Table 2 reports the results of a linear regression predicting when Uber enters an MSA. The independent variables are measured in standard deviation units to facilitate comparison of the magnitudes of the coefficients. We 


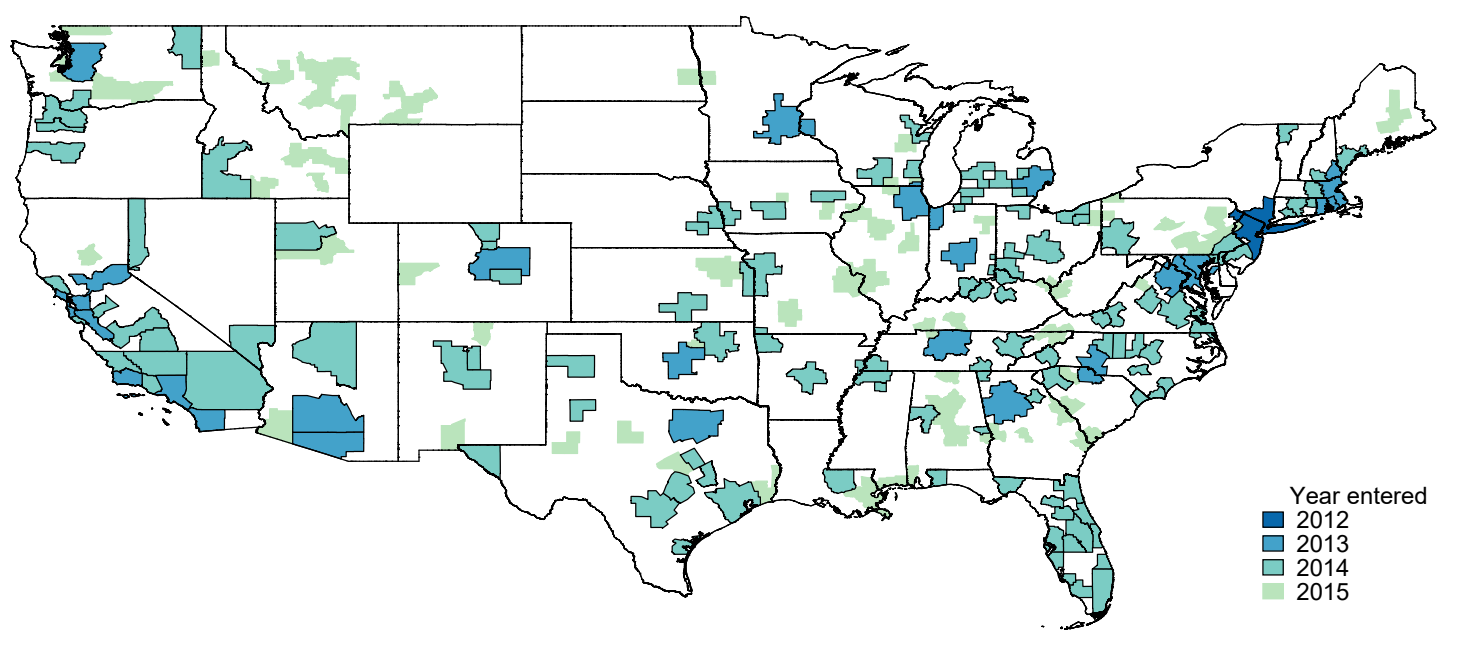

Figure 4: Map of when Uber entered each MSA

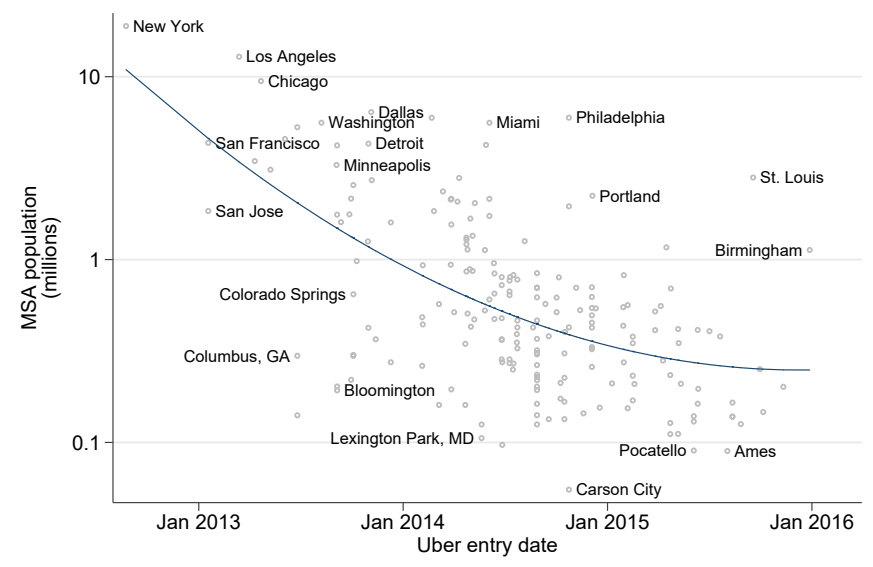

Figure 5: Uber entry date by MSA population

Notes: Data on population from the 2008-2012 American Community Survey 5-year estimates. Data on when Uber entered each MSA collected by the authors. The fitted line is from a quadratic regression of log population on date of entry. 
find that population is the strongest predictor of when Uber enters an MSA, with an effect double that of any other predictor. We also find that the levels matter more than trends, meaning Uber cares more about being in large cities rather than in growing cities, and rich cities more than cities getting richer. These results increase our confidence that Uber enters markets largely in order of their population rank.

Population and education levels are also the best predictor of whether Uber enters an MSA. The second column of Table 2 reports the result from a linear regression predicting whether Uber has entered an MSA. Once again, population is the strongest predictor of whether Uber enters an MSA: the coefficient on population is more than 60 percent larger than the next largest. The three largest MSAs without Uber are all in New York, as Uber was banned in upstate New York prior to June of 2017. ${ }^{14}$ Kendall's rank correlation between population and whether Uber has ever entered is .49.

These results suggest that Uber has focused on entering larger cities first, and gives us confidence that their entry decision is uncorrelated with other trends in public transit ridership.

\section{Estimating Uber's effect on transit}

We start with a visual summary of the transit ridership data in Figure 6. This figure plots the difference in $\log$ transit ridership for transit agencies who had Uber in their MSA relative to those who did not, using a 24 month-window before and after Uber's entry. The difference in log transit ridership the month before Uber enters is normalized to zero. Figure 6 shows no significant pre-trend, suggesting that, given our set of controls and MSA-specific-linear-time-trends, the parallel trends assumption holds.

Additionally, Figure 6 shows that transit ridership increases slowly after Uber enters an MSA, until two years after Uber's entry transit ridership is 5-8 percent higher than it would have otherwise been. While only one of the month-specific estimates is statistically significant at the 5 percent level, we can reject the joint hypothesis that all of the month-specific estimates after Uber's entry are zero.

Table 3 reports our estimates for the effect of Uber on overall transit ridership.

\footnotetext{
${ }^{14}$ Nir, Sarah Maslin and James Barron. 2017. "Relief and Trepidation as Ride Hailing Spreads Across New York." The New York Times. 3 July 2017.
} 
Table 2: Linear regressions predicting when and whether Uber enters an MSA

Date UberX entry Did UberX enter

(1)

$(2)$

\begin{tabular}{lcc}
\hline $\log ($ population $)(\sigma)$ & $-103.2^{* * *}$ & $0.256^{* * *}$ \\
& $(4.690)$ & $(0.00705)$ \\
Percent with bachelor's degree $(\sigma)$ & $-41.77^{* * *}$ & $0.180^{* * *}$ \\
& $(5.108)$ & $(0.00857)$ \\
Median age $(\sigma)$ & $30.90^{* * *}$ & $-0.0518^{* * *}$ \\
& $(5.777)$ & $(0.00844)$ \\
Median income $(\sigma)$ & $-11.40^{* *}$ & $-0.0288^{* * *}$ \\
& $(4.905)$ & $(0.00963)$ \\
Excess unemployment $(\sigma)$ & $-41.73^{* * *}$ & $0.0336^{* * *}$ \\
& $(4.713)$ & $(0.00789)$ \\
Percent work trips transit $(\sigma)$ & $-9.956^{* *}$ & $-0.0792^{* * *}$ \\
& $(4.968)$ & $(0.00948)$ \\
Capital expenditures on public transit $(\sigma)$ & -4.868 & -0.00152 \\
& $(4.939)$ & $(0.00698)$ \\
Dist from Uber HQ $(\sigma)$ & $11.99^{* * *}$ & 0.00823 \\
& $(4.389)$ & $(0.00662)$ \\
Trend in log(population) $(\sigma)$ & 11.46 & $0.0214^{*}$ \\
& $(8.225)$ & $(0.0120)$ \\
Trend in median income $(\sigma)$ & 1.641 & -0.0298 \\
& $(13.65)$ & $(0.0204)$ \\
\hline Observations & 197 & 386 \\
Adjusted R-squared & 0.383 & 0.394 \\
\hline
\end{tabular}

Notes: Data on when Uber entered each MSA collected by the authors. Data on population, income, age, and education from the 2008-2012 American Community Survey 5-year estimates. Excess unemployment is the difference between the unemployment rate in 2012 and the mean unemployment rate between 2004-2015, and this data is from the Bureau of Labor Statistics. Capital expenditures on public transit is the total per capita between 2008-2012. Capital expenditure data is from the National Transit Database. Linear trends in population and median income are estimated using the American Community Survey 1-year estimates from 2008-2012. All independent variables are measured in standard deviation units. Standard errors are calculated by bootstrapping with one thousand draws and are in parentheses. The bootstrap procedure includes the estimation of the linear trends.

${ }^{*} p<.10 ;{ }^{* *} p<.05 ;{ }^{* * *} p<.01$ 


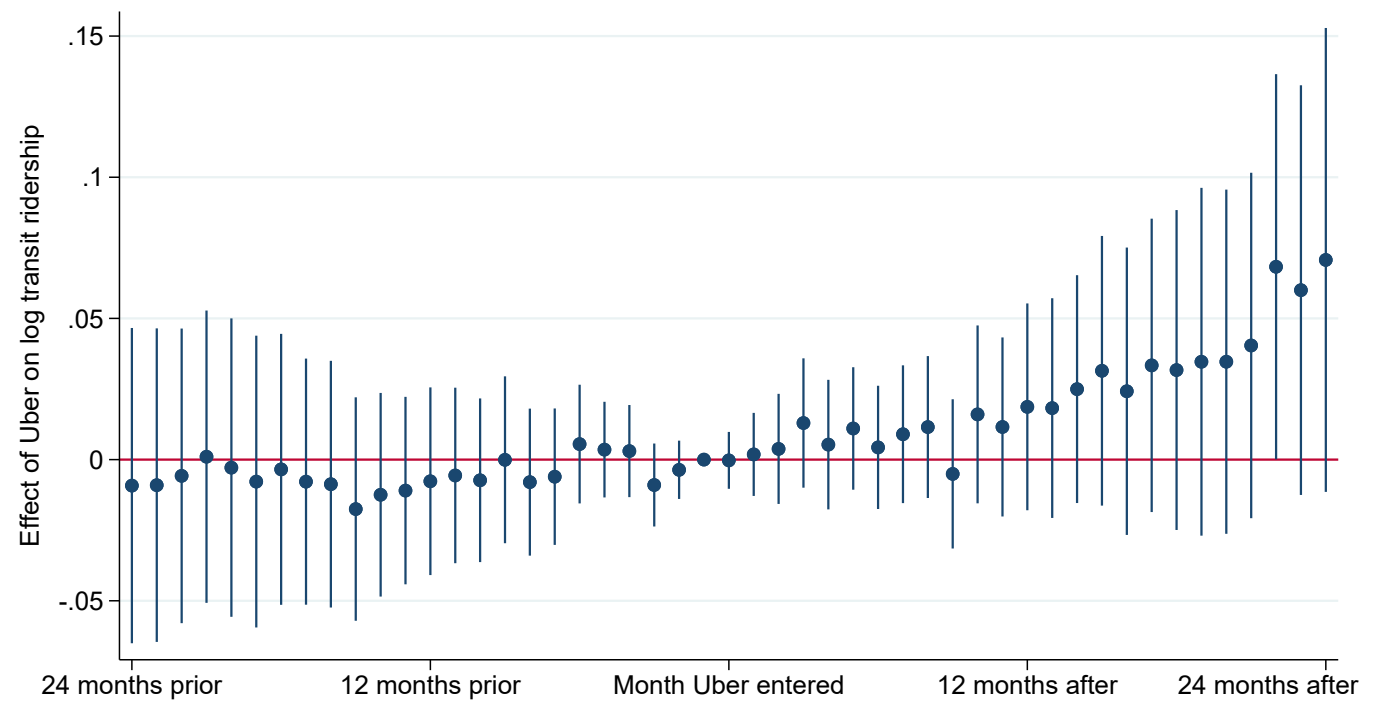

Figure 6: Effect of Uber on log transit ridership before and after entry

Notes: This figure plots the coefficients from a Autor (2003)-style regression of log transit ridership on leads and lags of Uber entry, as well as the controls and fixed effects in our base specification. The omitted indicator is the month before Uber enters. Bars denote 95 percent confidence intervals.

Our outcome variables are all measured in logs so the coefficients represent the percent increase in public transit ridership that accompanies the arrival or increased penetration of Uber. Column 1 confirms what Figure 6 shows, that when Uber arrives in an MSA, transit ridership does not change much, with a coefficient that indicates there is a 0.26 percent increase in public transit use which is not statistically significant. However, the results in Column 5 indicate that as Uber becomes more commonly used in the MSA, there is an increase in public transit use, with a standard deviation increase in Uber penetration increasing public transit ridership by 1.4 percent. This is consistent with the slowly growing effect of Uber on transit ridership shown in Figure 6.

One reason Uber is a complement rather than a substitute for the average transit agency may be that transit is still much cheaper to use. The median minimum Uber fare is $\$ 5$, while transit fares average just $\$ 1$. Undiscounted fares for bus or light rail are never above $\$ 3$, and for those with a monthly pass the marginal fare is zero. Transit is cheaper by enough that Uber's role in adding flexibility to the transit system is more important than its ability to substitute for riding transit.

This average treatment effect masks considerable heterogeneity in the effect 
Table 3: Effect of Uber on log transit ridership

\begin{tabular}{|c|c|c|c|c|c|c|c|c|}
\hline & \multicolumn{4}{|c|}{ Uber entry } & \multicolumn{4}{|c|}{ Uber penetration } \\
\hline & (1) & (2) & (3) & $(4)$ & (5) & (6) & (7) & (8) \\
\hline UberX & $\begin{array}{l}0.00263 \\
(0.0143)\end{array}$ & $\begin{array}{c}-0.0591^{* *} \\
(0.0295)\end{array}$ & $\begin{array}{c}0.0598^{* *} \\
(0.0236)\end{array}$ & $\begin{array}{c}-0.00190 \\
(0.0364)\end{array}$ & $\begin{array}{c}0.0138^{* * *} \\
(0.00515)\end{array}$ & $\begin{array}{c}-0.00483 \\
(0.00526)\end{array}$ & $\begin{array}{c}0.0328^{* * *} \\
(0.00652)\end{array}$ & $\begin{array}{c}0.00758 \\
(0.00677)\end{array}$ \\
\hline $\begin{array}{l}\text { Above median population } \\
\quad \times \text { UberX }\end{array}$ & & $\begin{array}{l}0.0666^{* *} \\
(0.0294)\end{array}$ & & $\begin{array}{l}0.0665^{* *} \\
(0.0307)\end{array}$ & & $\begin{array}{l}0.0228^{* * *} \\
(0.00716)\end{array}$ & & $\begin{array}{l}0.0343^{* * *} \\
(0.00796)\end{array}$ \\
\hline $\begin{array}{l}\text { Above median ridership } \\
\times \text { UberX }\end{array}$ & & & $\begin{array}{c}-0.0811^{* * *} \\
(0.0292)\end{array}$ & $\begin{array}{c}-0.0811^{* * *} \\
(0.0292)\end{array}$ & & & $\begin{array}{c}-0.0281^{* * *} \\
(0.00977)\end{array}$ & $\begin{array}{c}-0.0323^{* * *} \\
(0.0100)\end{array}$ \\
\hline Observations & 71,386 & 71,386 & 71,386 & 71,386 & 58,015 & 58,015 & 58,015 & 58,015 \\
\hline Clusters & 309 & 309 & 309 & 309 & 227 & 227 & 227 & 227 \\
\hline
\end{tabular}

Notes: Controls are the log of the following: average fare, the maximum number of vehicles in service during the month, vehicle-hours of service, vehicle-miles of service, regional gas prices, employment, and population. Includes a linear MSA time-trend and fixed effects for each monthyear, transit agency, and transit agency-calendar month pair. Median population is calculated among the set of MSAs with public transportation. Median ridership is calculated based on mean ridership before Uber existed. Uber penetration is measured using Google Trends and reported in standard deviation units. Standard errors are reported in parentheses and clustered at the MSA level.

${ }^{*} p<.1 ;{ }^{* *} p<.05 ;{ }^{* * *} p<.01$

of Uber on transit. We expand our analysis to examine how the effect of Uber differs based on the population of the MSA and the number of riders that were using public transit before Uber arrived. For both of these measures, we split the sample based on whether an observation is above or below our sample median and include each of these binary variables as an interaction term with our Uber measures. The median population is 280,000 and median monthly ridership is 82,000 . Table 4 reports example of transit agencies with each possible combination of our dummy variables for ridership and population. The big transit agencies in small cities are almost always in university towns, while small agencies in big cities are a mix of suburban agencies and cities with limited public transit.

Our results indicate that Uber reduces transit ridership in smaller MSAs while increasing ridership in larger cities. In fact, the coefficients in Table 3 indicate that the arrival of Uber in smaller cities decreases public transit ridership by 5.9 percent while increasing public transit ridership by 0.8 percent for agencies in the larger cities. Our estimates based on the Uber penetration rates indicate that a standard deviation increase in Uber use lowers public transit ridership for agencies in smaller cities by 0.5 percent while increasing ridership in larger cities by 1.8 
Table 4: Examples of transit agencies by ridership and MSA size

Population

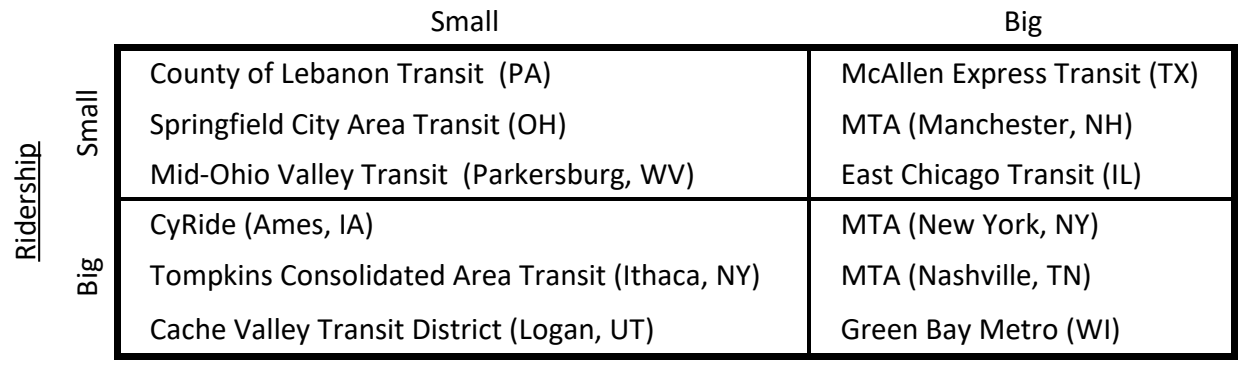

Notes: Big and small are defined relative to the median.

percent.

In contrast, we find that Uber actually had the largest effects for transit agencies that had smaller levels of initial ridership prior to Uber's founding. For the transit agencies that had below median public transit ridership, the arrival of Uber increased public transit use by 6 percent while for the transit agencies with above median ridership, it decreased public transit use by 2.1 percent. All of these estimates are roughly the same whether or not we simultaneously control for population and pre-Uber public transit ridership.

Uber most strongly complements small transit agencies in large cities. This is likely because a small transit agency in a large city provides the least flexible service in terms of when and where they travel, and so Uber's ability to add flexibility for such agencies is valuable to riders. ${ }^{15}$ In addition, transit riders in larger cities tend to be wealthier, and so there is greater overlap between those who ride transit and can afford to take Uber. ${ }^{16}$

Such heterogeneous effects across cities and agencies suggest exploring their

\footnotetext{
${ }^{15}$ Consistent with this interpretation, in 2016 and 2017 some cities partnered with Uber to supplement or replace weaker public transit services. Three cities ran such programs: Tampa, FL; Dublin, CA; and Philadelphia, PA. All such partnerships began after our data end and should not affect our results. In results not reported in this paper, dropping these three MSAs from our sample did not alter the results. See Zwick and Spicer (2018) for a more detailed discussion of why and how cities partner with Uber.

${ }^{16}$ While our data do not allow us to observe characteristics of people who use Uber or public transit, the Pew Study reveals some important demographic information. Compared to Americans who had never used Uber, Americans who had used Uber by 2016 were significantly more likely to earn more than $\$ 75,000$ a year and to have graduated college. In the same study, there were no meaningful differences in income or education between Uber users who do and do not use public transit.
} 
correlation with Uber uptake. In Table 5 we estimate how Uber entry affects Uber penetration, using Google Trends as a proxy. ${ }^{17}$ Because Google Trends does not vary across agencies within an MSA, we run the regressions at the MSA level. Changing the level of observation does not affect the population variable, but it does force us to redefine our "above median ridership" variable. We use two alternatives to denote MSAs with smaller transit agencies: (1) whether the MSA has at least one below median ridership agency, (2) the number of transit agencies. Unsurprisingly, Uber entry significantly increases Google searches for Uber. When we allow the effect to differ by population and transit agency characteristics, we find Uber's penetration is highest in large cities as well as in MSAs with at least one small transit agency. Uber penetration also increases with the number of transit agencies servicing the MSA. Because Uber penetration is higher in the same places where Uber is complementing transit, the evidence supports the hypothesis that Uber is a net complement to transit.

Table 6 reports the result of estimating the effect of Uber on bus ridership and train ridership. It shows that the results for bus ridership are similar to those for total ridership. The point estimates are of the same sign, though we have fewer observations and thus less power, so they are typically less statistically significant. However, Uber's effect on rail ridership is different from its effect on bus and overall ridership. In particular, Uber now helps larger agencies relative to smaller agencies.

The results by mode of transportation also highlight some of the potential ways in which the effects of Uber may have spillover effects for transit agencies in the same MSA. For example, combining the main effect of Uber penetration with the interaction effect for being in a large city indicates that in large cities with low public transit use to begin with, a standard deviation increase in Uber penetration results in a $2.96 \%$ increase in bus ridership but a $0.76 \%$ decrease in train ridership. Thus while the overall effect of Uber on total public transit use is positive in these cities, there is potentially some shifting of train ridership towards bus ridership.

These estimates weight all transit agencies identically, and thus are estimates of how Uber affects the typical transit agency. To instead estimate how Uber effects national transit ridership, in Panel A of Table A.2 we report results where each

\footnotetext{
${ }^{17}$ In Section 3 we demonstrated that Google Trends is a suitable proxy for the number of Uber drivers per capita, and thus a good proxy for Uber's market penetration.
} 
Table 5: Effect of Uber entry on Uber penetration

\begin{tabular}{lcccccc}
\hline & $(1)$ & $(2)$ & $(3)$ & $(4)$ & $(5)$ & $(6)$ \\
\hline UberX & $0.470^{* * *}$ & 0.111 & $0.266^{* * *}$ & -0.0749 & $0.252^{* * *}$ & 0.0135 \\
& $(0.0543)$ & $(0.125)$ & $(0.0767)$ & $(0.141)$ & $(0.0840)$ & $(0.128)$ \\
Above median population & & $0.418^{* * *}$ & & $0.401^{* * *}$ & & $0.292^{* *}$ \\
$\quad \times$ UberX & & $(0.139)$ & & $(0.138)$ & & $(0.141)$ \\
$\quad$ Has below median agency & & & $0.499^{* * *}$ & $0.492^{* * *}$ & & \\
$\quad \times$ UberX & & & $(0.133)$ & $(0.130)$ & & \\
Number of transit agencies & & & & & $0.0681^{* *}$ & $0.0642^{* *}$ \\
$\quad \times$ UberX & & & & & $(0.0288)$ & $(0.0281)$ \\
\hline Observations & 29,854 & 29,854 & 29,854 & 29,854 & 29,854 & 29,854 \\
Clusters & 229 & 229 & 229 & 229 & 229 & 229 \\
\hline
\end{tabular}

Notes: The dependent variable in each regression is the Google Trends measure of searches for Uber in the MSA, measured in standard deviation units. Controls are the log of regional gas prices, employment, and population. Regressions include a linear MSA time-trend and fixed effects for each month-year, MSA, and MSA-calendar month pair. Median population is calculated among the set of MSAs with public transportation. Median ridership is calculated based on mean ridership before Uber existed. Standard errors are reported in parentheses and clustered at the MSA level. ${ }^{*} p<.1 ;{ }^{* *} p<.05 ;{ }^{* * *} p<.01$ 
Table 6: Effect of Uber on log bus ridership and log rail ridership

\begin{tabular}{|c|c|c|c|c|c|c|c|c|}
\hline & \multicolumn{4}{|c|}{ Bus } & \multicolumn{4}{|c|}{ Rail } \\
\hline & \multicolumn{2}{|c|}{ Uber entry } & \multicolumn{2}{|c|}{ Uber penetration } & \multicolumn{2}{|c|}{ Uber entry } & \multicolumn{2}{|c|}{ Uber penetration } \\
\hline & (1) & (2) & (3) & (4) & (5) & (6) & (7) & (8) \\
\hline UberX & $\begin{array}{c}0.0189 \\
(0.0166)\end{array}$ & $\begin{array}{c}0.0168 \\
(0.0327)\end{array}$ & $\begin{array}{l}0.0153^{* * *} \\
(0.00456)\end{array}$ & $\begin{array}{c}0.00243 \\
(0.00592)\end{array}$ & $\begin{array}{c}-0.0312 \\
(0.0194)\end{array}$ & $\begin{array}{l}-0.103^{*} \\
(0.0533)\end{array}$ & $\begin{array}{l}0.00370 \\
(0.0179)\end{array}$ & $\begin{array}{l}-0.0274 \\
(0.0245)\end{array}$ \\
\hline $\begin{array}{l}\text { Above median population } \\
\times \text { UberX }\end{array}$ & & $\begin{array}{c}0.0383 \\
(0.0302)\end{array}$ & & $\begin{array}{l}0.0272^{* * *} \\
(0.00891)\end{array}$ & & $\begin{array}{c}0.0365 \\
(0.0583)\end{array}$ & & $\begin{array}{c}0.0198 \\
(0.0207)\end{array}$ \\
\hline $\begin{array}{l}\text { Above median ridership } \\
\quad \times \text { UberX }\end{array}$ & & $\begin{array}{c}-0.0465^{* *} \\
(0.0221)\end{array}$ & & $\begin{array}{c}-0.0131 \\
(0.00845)\end{array}$ & & $\begin{array}{l}0.0771^{* *} \\
(0.0363)\end{array}$ & & $\begin{array}{c}0.0215 \\
(0.0152) \\
\end{array}$ \\
\hline Observations & 53,295 & 53,295 & 42,673 & 42,673 & 7,427 & 7,427 & 7,360 & 7,360 \\
\hline Clusters & 294 & 294 & 216 & 216 & 45 & 45 & 43 & 43 \\
\hline
\end{tabular}

Notes: Controls are the log of the following: average fare, the maximum number of vehicles in service during the month, vehicle-hours of service, vehicle-miles of service, regional gas prices, employment, and population. Includes a linear MSA time-trend and fixed effects for each monthyear, transit agency, and transit agency-calendar month pair. Median population is calculated among the set of MSAs with the given mode of public transportation. Median ridership calculated based on mean ridership before Uber existed and among the set of agencies with the given mode of public transportation. Uber penetration measured using Google Trends and reported in standard deviation units. Standard errors are reported in parentheses and clustered at the MSA level.

${ }^{*} p<.1 ; * *<.05 ;{ }^{* * *} p<.01$ 
transit agency is weighted by their average ridership prior to Uber's existence. Consistent with the finding that Uber hurts larger transit agencies and helps smaller agencies, we estimate very small and statistically insignificant effects of Uber on ridership. The heterogeneous effects estimated above remain.

In the appendix we conduct eight robustness tests. First, Figure A.1 plots the event study of how transit ridership changes when Uber enters a city, and gives similar results to Figure 6, though with larger standard errors. As mentioned earlier, in Table A.1 we show that using the number of active Uber drivers per capita gives similar results to using the Google Trends search index (both when compared to our entire sample, and when compared to the 16 cities for which we have data on the number of active drivers). Table A.2 shows our results are robust to a number of alternate specifications. Panel B shows that our results are robust to using population density, rather than population, as an interaction variable for Uber's effect on public transit ridership. Panel $\mathrm{C}$ shows our results are robust to leaving out New York City and in Panel D we address the concern that the controls are endogenous by showing our results are robust to leaving out the controls. Next, while we clustered our standard errors at the MSA level to address the serial correlation in the outcomes, Table A.3 shows our results are robust to alternative corrections to this problem. First, in Panel A, we calculate standard errors by block bootstrapping, and, second, in Panels B and C, we conduct placebo tests where we randomly assign treatment status and treatment date. We conduct this placebo test under two different assumptions about the data generating process. In the first we randomly re-assign the observed treatment variables at the MSAmonth level, while in the second we randomly assign which cities Uber enters and when. For this second test using the penetration data, we assign treated cities a penetration history from an MSA which was actually treated and adjust the timing to match the placebo treatment date. For untreated cities, we randomly assign a penetration history from an MSA which was not treated. We then calculate $\mathrm{p}$-values by comparing the $\mathrm{t}$-statistic from our main results to those generated by two thousand placebo treatments. 


\subsection{Estimating Uber's effect on commute times}

Because the above results show that Uber changes how people travel, it also could affect commute times. However, it is hard to predict how Uber should affect them. For those who use Uber for the first or last mile of a trip, commute times will fall. For those who begin taking public transit because Uber has lowered the total cost by making transit more convenient or reliable, the change in commute times is indeterminate since commuters might be willing to accept longer commute times for the lower total cost. ${ }^{18}$ Even if commute times fall for all Uber users, the effect on average commute times depends on whether Uber significantly increases congestion, which would increase commute times for other commuters.

We estimate how Uber affects average commute times using the American Community Survey (ACS) data for each MSA. In Table 7, using the same identification strategy as our main results, we find that Uber's entry increases commute times in larger cities with small transit agencies, the same MSAs where we see transit usage increase. We also find that as Uber's penetration increases in an MSA, commutes get longer. The effect does not vary across MSA size or transit characteristics. The effects are consistent with Uber leading people to switch to transit, leading to longer commutes, but also may be indicative of Uber increasing traffic congestion.

To disentangle the effects on transit usage and congestion, we take advantage of the ACS data on commute times by primary mode of transit. This analysis is speculative because the data are repeated cross-sections, not panel, and Uber affects the composition of the groups, but it is worth examining. In Tables 8 and 9 we estimate the effect of Uber on commuters using public transportation and private vehicle. For public transportation users, the coefficients are large and negative, but the results are not statistically significant, and commute times for private vehicle commuters in large MSAs or those with a small transit agency increased by 1.5-2.5 percent. Together these results suggest that Uber reduced commute times for public transit users while increasing congestion.

\footnotetext{
${ }^{18}$ Total costs includes, in additional to travel time, financial costs and reliability.
} 
Table 7: Effect of Uber on log commute times

\begin{tabular}{|c|c|c|c|c|c|c|}
\hline & \multicolumn{3}{|c|}{ Uber entry } & \multicolumn{3}{|c|}{ Uber penetration } \\
\hline & (1) & (2) & (3) & (4) & (5) & (6) \\
\hline UberX & $\begin{array}{c}0.00322 \\
(0.00538)\end{array}$ & $\begin{array}{l}-0.0164^{*} \\
(0.00889)\end{array}$ & $\begin{array}{c}-0.0125 \\
(0.00909)\end{array}$ & $\begin{array}{c}0.00883^{* * *} \\
(0.00312)\end{array}$ & $\begin{array}{l}0.00859^{*} \\
(0.00514)\end{array}$ & $\begin{array}{l}0.0107^{* *} \\
(0.00487)\end{array}$ \\
\hline $\begin{array}{l}\text { Above median population } \\
\quad \times \text { UberX }\end{array}$ & & $\begin{array}{l}0.0217^{* * *} \\
(0.00804)\end{array}$ & $\begin{array}{c}0.0153^{*} \\
(0.00843)\end{array}$ & & $\begin{array}{c}-0.0000711 \\
(0.00380)\end{array}$ & $\begin{array}{l}-0.00283 \\
(0.00353)\end{array}$ \\
\hline $\begin{array}{l}\text { Has below median agency } \\
\quad \times \text { UberX }\end{array}$ & & $\begin{array}{l}0.0201^{*} \\
(0.0108)\end{array}$ & & & $\begin{array}{c}0.00507 \\
(0.00443)\end{array}$ & \\
\hline $\begin{array}{l}\text { Number of transit agencies } \\
\times \text { UberX }\end{array}$ & & & $\begin{array}{c}0.000824 \\
(0.000660)\end{array}$ & & & $\begin{array}{r}0.000130 \\
(0.000233)\end{array}$ \\
\hline Observations & 2,672 & 2,672 & 2,672 & 2,018 & 2,018 & 2,018 \\
\hline Clusters & 305 & 305 & 305 & 222 & 222 & 222 \\
\hline
\end{tabular}

Notes: The dependent variable in each regression is the log of the average commute time reported in the one-year American Community Survey estimates. Controls are the log of employment, population, and regional gas prices. Regressions include a linear MSA time-trend and fixed effects for each month-year, transit agency, and transit agency-calendar month pair. Median population is calculated among the set of MSAs with public transportation. Median ridership calculated based on mean ridership before Uber existed. Uber penetration measured using Google Trends and reported in standard deviation units. Standard errors are reported in parentheses and clustered at the MSA level.

${ }^{*} p<.1 ;{ }^{* *} p<.05 ;{ }^{* * *} p<.01$ 
Table 8: Effect of Uber on log public transportation commute times

\begin{tabular}{|c|c|c|c|c|c|c|}
\hline & \multicolumn{3}{|c|}{ Uber entry } & \multicolumn{3}{|c|}{ Uber penetration } \\
\hline & (1) & (2) & (3) & (4) & (5) & (6) \\
\hline UberX & $\begin{array}{l}-0.0141 \\
(0.0296)\end{array}$ & $\begin{array}{l}-0.0552 \\
(0.0556)\end{array}$ & $\begin{array}{l}-0.0635 \\
(0.0531)\end{array}$ & $\begin{array}{r}-0.00475 \\
(0.0116)\end{array}$ & $\begin{array}{l}-0.0203 \\
(0.0319)\end{array}$ & $\begin{array}{c}-0.00538 \\
(0.0272)\end{array}$ \\
\hline $\begin{array}{l}\text { Above median population } \\
\quad \times \text { UberX }\end{array}$ & & $\begin{array}{c}0.0539 \\
(0.0487)\end{array}$ & $\begin{array}{c}0.0711 \\
(0.0460)\end{array}$ & & $\begin{array}{c}0.0139 \\
(0.0273)\end{array}$ & $\begin{array}{l}0.00418 \\
(0.0241)\end{array}$ \\
\hline $\begin{array}{l}\text { Has below median agency } \\
\quad \times \text { UberX }\end{array}$ & & $\begin{array}{l}-0.0488 \\
(0.0853)\end{array}$ & & & $\begin{array}{c}0.0227 \\
(0.0338)\end{array}$ & \\
\hline $\begin{array}{l}\text { Number of transit agencies } \\
\times \text { UberX }\end{array}$ & & & $\begin{array}{l}-0.00272^{*} \\
(0.00148)\end{array}$ & & & $\begin{array}{l}-0.000477 \\
(0.000498)\end{array}$ \\
\hline Observations & 2,644 & 2,644 & 2,644 & 2,001 & 2,001 & 2,001 \\
\hline Clusters & 305 & 305 & 305 & 222 & 222 & 222 \\
\hline
\end{tabular}

Notes: The dependent variable in each regression is the log of the average commute time by public transportation reported in the one-year American Community Survey estimates. Controls are the log of employment, population, and regional gas prices. Regressions include a linear MSA time-trend and fixed effects for each month-year, transit agency, and transit agency-calendar month pair. Median population is calculated among the set of MSAs with public transportation. Median ridership calculated based on mean ridership before Uber existed. Uber penetration measured using Google Trends and reported in standard deviation units. Standard errors are reported in parentheses and clustered at the MSA level.

${ }^{*} p<.1 ;{ }^{* *} p<.05 ;{ }^{* * *} p<.01$ 
Table 9: Effect of Uber on log private automobile commute times

\begin{tabular}{lcccccccc}
\hline & \multicolumn{3}{c}{ Uber entry } & & \multicolumn{3}{c}{ Uber penetration } \\
\cline { 2 - 4 } \cline { 7 - 8 } & $(1)$ & $(2)$ & $(3)$ & & $(4)$ & $(5)$ & $(6)$ \\
\hline UberX & 0.00507 & -0.0113 & -0.00615 & & $0.00687^{* *}$ & 0.00610 & 0.00836 \\
& $(0.00521)$ & $(0.00942)$ & $(0.00973)$ & & $(0.00293)$ & $(0.00595)$ & $(0.00579)$ \\
Above median population & & $0.0174^{* *}$ & 0.00988 & & 0.000424 & -0.00263 \\
$\quad \times$ UberX & & $(0.00849)$ & $(0.00895)$ & & $(0.00468)$ & $(0.00431)$ \\
$\quad$ Has below median agency & & $0.0246^{* *}$ & & & 0.00555 & \\
$\quad \times$ UberX & & $(0.0114)$ & & & $(0.00521)$ & \\
$\quad$ Number of transit agencies & & & 0.000829 & & & 0.000156 \\
$\quad \times$ UberX & & & $(0.000538)$ & & & $(0.000218)$ \\
\hline Observations & 2,672 & 2,672 & 2,672 & & 2,018 & 2,018 & 2,018 \\
Clusters & 305 & 305 & 305 & & 222 & 222 & 222 \\
\hline
\end{tabular}

Notes: The dependent variable in each regression is the log of the average commute time by private automobile reported in the one-year American Community Survey estimates. Controls are the log of employment, population, and regional gas prices. Regressions include a linear MSA time-trend and fixed effects for each month-year, transit agency, and transit agency-calendar month pair. Median population is calculated among the set of MSAs with public transportation. Median ridership calculated based on mean ridership before Uber existed. Uber penetration measured using Google Trends and reported in standard deviation units. Standard errors are reported in parentheses and clustered at the MSA level.

${ }^{*} p<.1 ; * * p<.05 ;{ }^{* * *} p<.01$ 


\section{Conclusion}

Uber and other ride-hailing companies have changed how people get around in cities worldwide. How this has impacted public transit matters both for assessing the welfare effects of Uber and for cities deciding how to regulate Uber. However, Uber's effect on transit is theoretically ambiguous: while Uber is an alternative mode of travel, it can also increase the reach and flexibility of transit's fixed-route, fixed-schedule service. The results in this paper employ a difference-in-differences design that exploits variation across U.S. metropolitan areas in both the intensity of Uber penetration and the timing of Uber entry. We find that Uber's entry increases public transit use for the average transit agency and that the effect grows over time.

Exploring the heterogeneity behind the average effect, we find that Uber is a complement to small transit agencies and to agencies in large cities. The data

are insufficient for probing the mechanism behind the heterogeneity, but there are some clear candidates. The complementary effect for small transit agencies suggests customers are using Uber to circumvent the fixed-route, fixed-schedule problem. Transit users in large cities have greater variation in income, and the complementary effects could come from the group of riders who can afford Uber. High-income riders could also explain why Uber has a large complementary effect on rail ridership and a negative effect on bus ridership: rail riders typically have higher incomes, while high-income bus riders might be willing to pay for a pricier Uber ride. The scope of this paper requires us to label such explanations as speculative, but richer data in future research could provide a more definitive answer.

The results from this paper provide further evidence that Uber increases welfare, although more work needs to be done before drawing definitive conclusions. Results from previous work indicated that Uber increases consumer surplus (Cohen et al. 2016), but, perhaps, with some cost to taxi driver earnings (Cramer 2016; Berger et al. 2018). This paper's results indicate that Uber has an additional effect on social welfare through encouraging use of public transit. In fact, Uber has the biggest complementary effects on the public transit systems that had the lowest ridership before Uber's entry. However, Uber seems to be decreasing ridership on larger systems, and our estimates suggest the effect on these systems counteracts 
the increase on smaller systems. Furthermore, while increasing public transit use would decrease congestion (Anderson 2014; Adler and van Ommeren 2016), Uber could still have a net increase on congestion by either increasing the total trips taken or by flooding the streets with Uber drivers looking for a fare. Exploring Uber's impact on urban transit and traffic warrants more attention.

The results also warn against making broad policy prescriptions regarding Uber. Uber's effect in a city varies based on the state of public transit. Thus the optimal policy response may also vary across cities.

Beyond contributing to our understanding of the effect of Uber on cities, this paper also provides preliminary insight into the economic impact of another technological innovation within urban transportation: autonomous vehicles. While there is much speculation about how autonomous vehicles may change cities, no empirical estimates exist to date because the technology is so new. However, inasmuch as the change from taxi to ride-hailing is similar to the change from ride-hailing to autonomous vehicles, in that autonomous vehicles will make trans-

portation more convenient, accessible and affordable, then our results provide suggestive evidence that autonomous vehicles may complement public transit, and that this effect will likely vary across cities.

\section{References}

Adler, Martin W. and Jos N. van Ommeren (2016). "Does Public Transit Reduce Car Travel Externalities? Quasi-Natural Experiments' Evidence from Transit Strikes," Journal of Urban Economics, Vol. 92, pp. 106-119.

American Public Transit Association (2018). 2017 APTA Fact Book, Washington, D.C.: American Public Transportation Association.

Anderson, Michael L. (2014). "Subways, Strikes, and Slowdowns: The Impacts of Public Transit on Traffic Congestion," American Economic Review, Vol. 104, pp. 2763-96.

Autor, David H. (2003). "Outsourcing at Will: The Contribution of Unjust Dismissal Doctrine to the Growth of Employment Outsourcing," Journal of Labor Economics, Vol. 21, pp. 1-42. 
Basso, Leonardo J. and Hugo E. Silva (2014). "Efficiency and Substitutability of Transit Subsidies and Other Urban Transport Policies," American Economic Journal: Economic Policy, Vol. 6, pp. 1-33.

Baum-Snow, Nathaniel (2007). "Did Highways Cause Suburbanization?" Quarterly Journal of Economics, Vol. 122, pp. 775-805.

Baum-Snow, Nathaniel and Matthew E. Kahn (2000). "The Effects of New Public Projects to Expand Urban Rail Transit," Journal of Public Economics, Vol. 77, pp. 241-263.

Berger, Thor, Chinchih Chen, and Carl Benedikt Frey (2018). “Drivers of Disruption? Estimating the Uber Effect," European Economic Review, Vol. 110, pp. 197-210.

Bertrand, Marianne, Esther Duflo, and Sendhil Mullainathan (2004). "How Much Should We Trust Differences-In-Differences Estimates?" Quarterly Journal of Economics, Vol. 119, pp. 249-275.

Brazil, Noli and David S. Kirk (2016). "Uber and Metropolitan Traffic Fatalities in the United States," American Journal of Epidemiology, Vol. 184, pp. 192-198.

Cohen, Peter, Robert Hahn, Jonathan Hall, Steven Levitt, and Robert Metcalfe (2016). "Using Big Data to Estimate Consumer Surplus: The Case of Uber," Working Paper 22627, National Bureau of Economic Research.

Cramer, Judd (2016). "The Effect of Uber on the Wages of Taxi and Limousine Drivers," Working Paper.

Dills, Angela K. and Sean E. Mulholland (2018). "Ride-Sharing, Fatal Crashes, and Crime," Southern Economic Journal, Vol. 84, pp. 965-991.

Gendron-Carrier, Nicolas, Marco Gonzalez-Navarro, Stefano Polloni, and Matthew Turner (2018). "Subways and Urban Air Pollution," Working Paper.

Goetzke, Frank (2008). “Network Effects in Public Transit Use: Evidence from a Spatially Autoregressive Mode Choice Model for New York," Urban Studies, Vol. 45 , pp. 407-417. 
Greenwood, Brad N. and Sunil Wattal (2017). "Show Me the Way to Go Home: An Empirical Investigation of Ride Sharing and Alcohol Related Motor Vehicle Homicide," MIS Quarterly, Vol. 41, pp. 163-188.

Hall, Jonathan V. and Alan B. Krueger (2018). "An Analysis of the Labor Market for Uber's Driver-Partners in the United States," ILR Review, Vol. 71, pp. 705-732.

Hoopes, Jeffrey L., Daniel H. Reck, and Joel Slemrod (2015). “Taxpayer Search for Information: Implications for Rational Attention," American Economic Journal: Economic Policy, Vol. 7, pp. 177-208.

Larcom, Shaun, Ferdinand Rauch, and Tim Willems (2017). "The Benefits of Forced Experimentation: Striking Evidence from the London Underground Network," Quarterly Journal of Economics, Vol. 132, pp. 2019-2055.

LeRoy, Stephen F. and Jon Sonstelie (1983). "Paradise Lost and Regained: Transportation Innovation, Income, and Residential Location," Journal of Urban Economics, Vol. 13, pp. 67-89.

Murphy, Colin and Sharon Feigon (2016). "Shared Mobility and the Transformation of Public Transit,"'Technical Report TCRP J-11/TASK 21, American Public Transportation Association, Washington, DC.

Nie, Yu (Marco) (2017). "How Can the Taxi Industry Survive the Tide of Ridesourcing? Evidence from Shenzhen, China," Transportation Research Part C: Emerging Technologies, Vol. 79, pp. 242-256.

Parry, Ian W. H. and Kenneth A. Small (2009). "Should Urban Transit Subsidies Be Reduced?" American Economic Review, Vol. 99, pp. 700-724.

Peck, Jessica Lynn (2017). “New York City Drunk Driving After Uber," Working Paper.

Pew Research Center (2016). Shared, Collaborative and On Demand: The New Digital Economy: Pew Research Center.

Proost, Stef and Kurt Van Dender (2008). "Optimal Urban Transport Pricing in the Presence of Congestion, Economies of Density and Costly Public Funds," Transportation Research Part A: Policy and Practice, Vol. 42, pp. 1220-1230. 
Rayle, Lisa, Danielle Dai, Nelson Chan, Robert Cervero, and Susan Shaheen (2016). "Just a Better Taxi? A Survey-Based Comparison of Taxis, Transit, and Ridesourcing Services in San Francisco," Transport Policy, Vol. 45, pp. 168-178.

Smith, Amy (2015). "Using Open Data and Uber Data to Understand How Ridesharing Complements Public Transportation," Washington, D.C.

Spicer, Zachary and Gabriel Eidelman (2017). "Global Cities, Local Disruption: Uber's Road to Regulatory Approval in Ten North American Cities," Working Paper.

Stephens-Davidowitz, Seth (2014). "The Cost of Racial Animus on a Black Candidate: Evidence Using Google Search Data," Journal of Public Economics, Vol. 118, pp. 26-40.

Wilson, Steven G., David A. Plane, Paul J. Mackun, Thomas R. Fischetti, and Justyna Goworowska (2012). "Patterns of Metropolitan and Micropolitan Population Change: 2000 to 2010," Report C2010SR-01, U.S. Census Bureau, Washington, D.C.

Zwick, Austin and Zachary Spicer (2018). "Why Do Cities Partner with Uber? Understanding Reasons and Models," Working Paper.

\section{A Robustness tests}

This appendix contains several alternate specifications, as discussed in the body of the paper, and shows that our results are robust to these other specifications. It also contains alternate ways of testing statistical significance. 


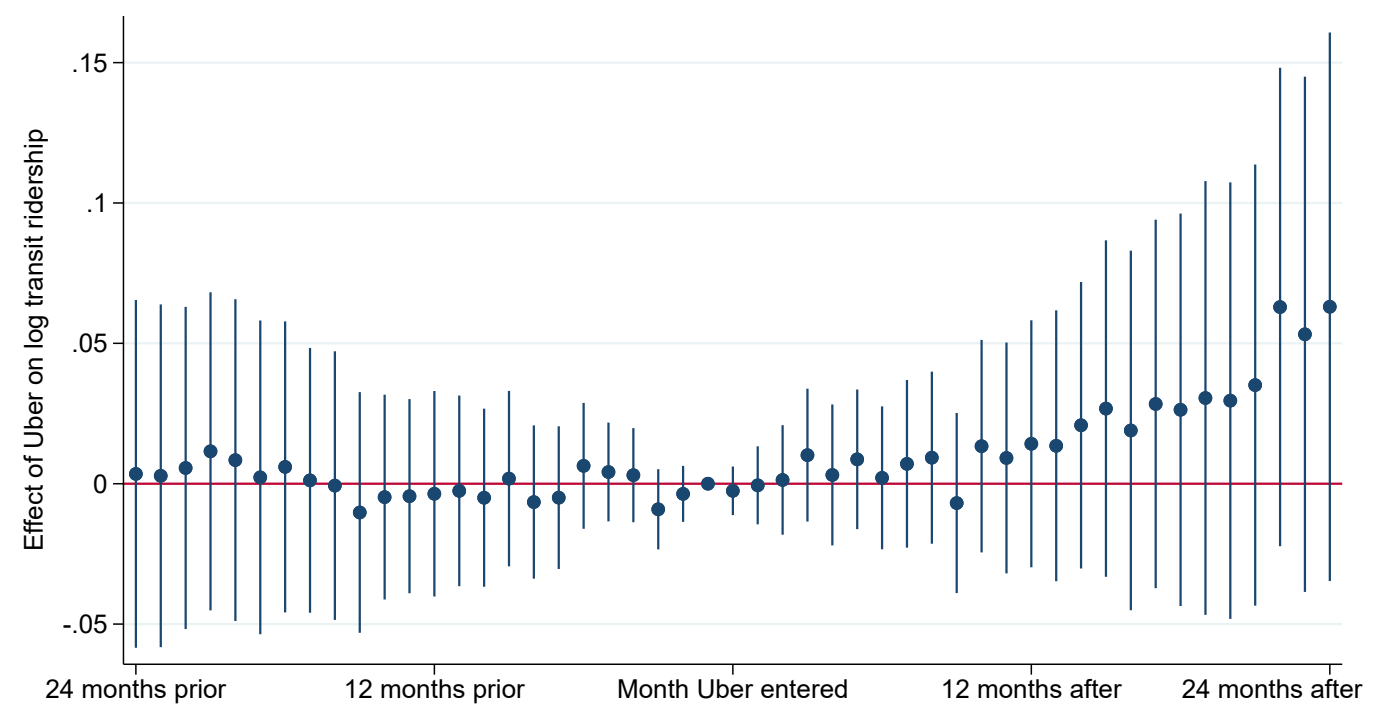

Figure A.1: Event study of effect of Uber on log transit ridership

Notes: This figure is the same as Figure 6, except that it is limited to those MSAs where Uber ever enters during our sample. The omitted indicator is the month before Uber enters. Bars denote 95 percent confidence intervals. 
Table A.1: Effect of the number of active Uber drivers per capita on log transit ridership

\begin{tabular}{|c|c|c|c|c|c|c|c|c|c|c|c|c|}
\hline & \multicolumn{4}{|c|}{ Total } & \multicolumn{4}{|c|}{ Bus } & \multicolumn{4}{|c|}{ Rail } \\
\hline & \multicolumn{2}{|c|}{ Active drivers } & \multicolumn{2}{|c|}{ Uber penetration } & \multicolumn{2}{|c|}{ Active drivers } & \multicolumn{2}{|c|}{ Uber penetration } & \multicolumn{2}{|c|}{ Active drivers } & \multicolumn{2}{|c|}{ Uber penetration } \\
\hline & (1) & (2) & (3) & (4) & (5) & (6) & (7) & (8) & (9) & (10) & (11) & (12) \\
\hline UberX & $\begin{array}{c}0.0258 \\
(0.0208)\end{array}$ & $\begin{array}{c}0.0787^{* * *} \\
(0.0227)\end{array}$ & $\begin{array}{c}0.0220 \\
(0.0238)\end{array}$ & $\begin{array}{l}0.0554^{* *} \\
(0.0248)\end{array}$ & $\begin{array}{l}0.00245 \\
(0.0198)\end{array}$ & $\begin{array}{c}0.0281 \\
(0.0213)\end{array}$ & $\begin{array}{c}0.0133 \\
(0.0282)\end{array}$ & $\begin{array}{c}0.0311 \\
(0.0298)\end{array}$ & $\begin{array}{c}0.0152 \\
(0.0223)\end{array}$ & $\begin{array}{l}-0.0144 \\
(0.0329)\end{array}$ & $\begin{array}{l}-0.0193 \\
(0.0238)\end{array}$ & $\begin{array}{l}-0.0294 \\
(0.0202)\end{array}$ \\
\hline $\begin{array}{l}\text { Above median ridership } \\
\quad \times \text { UberX }\end{array}$ & & $\begin{array}{c}-0.0636^{* * *} \\
(0.0167)\end{array}$ & & $\begin{array}{c}-0.0381^{* *} \\
(0.0142)\end{array}$ & & $\begin{array}{r}-0.0297^{* *} \\
(0.0112)\end{array}$ & & $\begin{array}{l}-0.0174 \\
(0.0112)\end{array}$ & & $\begin{array}{c}0.0339 \\
(0.0309)\end{array}$ & & $\begin{array}{c}0.0154 \\
(0.0211)\end{array}$ \\
\hline Observations & 19,047 & 19,047 & 19,047 & 19,047 & 13,342 & 13,342 & 13,342 & 13,342 & 4,377 & 4,377 & 4,377 & 4,377 \\
\hline Clusters & 16 & 16 & 16 & 16 & 16 & 16 & 16 & 16 & 16 & 16 & 16 & 16 \\
\hline
\end{tabular}

Notes: This table estimates the effect of the number of active Uber drivers per capita on transit ridership, and compares to estimates of the effect of our Uber penetration measure (Google Trends search intensity) on transit ridership for the same sample. The data on active drivers per capita is only available for 16 MSAs. We impute the number of active drivers to be zero prior to any Uber service being available in the MSA. Both treatment variables reported in standard deviation units. Above median ridership is calculated based on mean ridership before Uber existed and among the set of agencies with the given mode of public transportation. All other controls as in Table 3. Standard errors are reported in parentheses and clustered at the MSA level.

${ }^{*} p<.1 ;{ }^{* *} p<.05 ;{ }^{* * *} p<.01$ 
Table A.2: Alternate specifications for the effect of Uber on log public transit ridership

\begin{tabular}{|c|c|c|c|c|c|c|c|c|c|c|c|c|}
\hline & \multicolumn{4}{|c|}{ Total } & \multicolumn{4}{|c|}{ Bus } & \multicolumn{4}{|c|}{ Rail } \\
\hline & \multicolumn{2}{|c|}{ Uber entry } & \multicolumn{2}{|c|}{ Uber penetration } & \multicolumn{2}{|c|}{ Uber entry } & \multicolumn{2}{|c|}{ Uber penetration } & \multicolumn{2}{|c|}{ Uber entry } & \multicolumn{2}{|c|}{ Uber penetration } \\
\hline & (1) & (2) & (3) & (4) & $(5)$ & (6) & (7) & $(8)$ & (9) & (10) & (11) & (12) \\
\hline \multicolumn{13}{|c|}{ Panel A: Weighting by pre-Uber average ridership } \\
\hline UberX & $\begin{array}{l}-0.00801 \\
(0.00743)\end{array}$ & $\begin{array}{c}0.0413 \\
(0.0407)\end{array}$ & $\begin{array}{c}0.00374 \\
(0.00844)\end{array}$ & $\begin{array}{l}0.0242^{*} \\
(0.0131)\end{array}$ & $\begin{array}{l}-0.0107 \\
(0.0113)\end{array}$ & $\begin{array}{l}0.00840 \\
(0.0292)\end{array}$ & $\begin{array}{c}0.00797 \\
(0.00833)\end{array}$ & $\begin{array}{c}0.00576 \\
(0.00982)\end{array}$ & $\begin{array}{l}0.00195 \\
(0.0125)\end{array}$ & $\begin{array}{l}-0.104^{* *} \\
(0.0495)\end{array}$ & $\begin{array}{r}-0.00912 \\
(0.0139)\end{array}$ & $\begin{array}{l}-0.0325 \\
(0.0249)\end{array}$ \\
\hline $\begin{array}{l}\text { Above median population } \\
\times \text { UberX }\end{array}$ & & $\begin{array}{c}0.0494^{* *} \\
(0.0225)\end{array}$ & & $\begin{array}{c}0.0171^{*} \\
(0.00983)\end{array}$ & & $\begin{array}{l}0.00803 \\
(0.0276)\end{array}$ & & $\begin{array}{l}0.00936 \\
(0.0105)\end{array}$ & & $\begin{array}{l}0.0403 \\
(0.0379)\end{array}$ & & $\begin{array}{c}0.0161 \\
(0.0163)\end{array}$ \\
\hline $\begin{array}{l}\text { Above median ridership } \\
\quad \times \text { UberX }\end{array}$ & & $\begin{array}{c}-0.0987^{* * *} \\
(0.0362)\end{array}$ & & $\begin{array}{c}-0.0376^{* * *} \\
(0.0132)\end{array}$ & & $\begin{array}{l}-0.0272 \\
(0.0197)\end{array}$ & & $\begin{array}{l}-0.00704 \\
(0.00715)\end{array}$ & & $\begin{array}{l}0.0682^{*} \\
(0.0386)\end{array}$ & & $\begin{array}{l}0.00782 \\
(0.0161)\end{array}$ \\
\hline Observations & 70,981 & 70,981 & 57,634 & 57,634 & 53,065 & 53,065 & 42,481 & 42,481 & 7,393 & 7,393 & 7,326 & 7,326 \\
\hline Clusters & 308 & 308 & 227 & 227 & 293 & 293 & 216 & 216 & 44 & 44 & 42 & 42 \\
\hline \multicolumn{13}{|c|}{ Panel B: Interacting with population density } \\
\hline UberX & $\begin{array}{l}-0.0375^{*} \\
(0.0223)\end{array}$ & $\begin{array}{c}0.0179 \\
(0.0301)\end{array}$ & $\begin{array}{c}0.00237 \\
(0.00603)\end{array}$ & $\begin{array}{l}0.0165^{* *} \\
(0.00709)\end{array}$ & $\begin{array}{l}-0.0221 \\
(0.0263)\end{array}$ & $\begin{array}{l}0.00911 \\
(0.0301)\end{array}$ & $\begin{array}{l}-0.00276 \\
(0.00669)\end{array}$ & $\begin{array}{c}0.00209 \\
(0.00711)\end{array}$ & $\begin{array}{l}-0.0303 \\
(0.0431)\end{array}$ & $\begin{array}{l}-0.0614 \\
(0.0471)\end{array}$ & $\begin{array}{l}0.00140 \\
(0.0278)\end{array}$ & $\begin{array}{l}-0.00686 \\
(0.0269)\end{array}$ \\
\hline $\begin{array}{l}\text { Above median population density } \\
\quad \times \text { UberX }\end{array}$ & $\begin{array}{c}0.0459^{* *} \\
(0.0215)\end{array}$ & $\begin{array}{c}0.0483^{* *} \\
(0.0215)\end{array}$ & $\begin{array}{c}0.0131^{*} \\
(0.00732)\end{array}$ & $\begin{array}{l}0.0200^{* * *} \\
(0.00760)\end{array}$ & $\begin{array}{l}0.0484^{*} \\
(0.0250)\end{array}$ & $\begin{array}{l}0.0494^{* *} \\
(0.0249)\end{array}$ & $\begin{array}{l}0.0206^{* * *} \\
(0.00772)\end{array}$ & $\begin{array}{l}0.0230^{* * *} \\
(0.00831)\end{array}$ & $\begin{array}{l}-0.00118 \\
(0.0562)\end{array}$ & $\begin{array}{l}-0.0280 \\
(0.0509)\end{array}$ & $\begin{array}{l}0.00218 \\
(0.0238)\end{array}$ & $\begin{array}{r}-0.00503 \\
(0.0229)\end{array}$ \\
\hline $\begin{array}{l}\text { Above median ridership } \\
\times \text { UberX }\end{array}$ & & $\begin{array}{c}-0.0817^{* * *} \\
(0.0292)\end{array}$ & & $\begin{array}{c}-0.0297^{* * *} \\
(0.00988)\end{array}$ & & $\begin{array}{c}-0.0453^{* *} \\
(0.0220)\end{array}$ & & $\begin{array}{c}-0.0101 \\
(0.00768)\end{array}$ & & $\begin{array}{l}0.0888^{* *} \\
(0.0355)\end{array}$ & & $\begin{array}{c}0.0253 \\
(0.0152)\end{array}$ \\
\hline Observations & 71,386 & 71,386 & 58,015 & 58,015 & 53,295 & 53,295 & 42,673 & 42,673 & 7,427 & 7,427 & 7,360 & 7,360 \\
\hline Clusters & 309 & 309 & 227 & 227 & 294 & 294 & 216 & 216 & 45 & 45 & 43 & 43 \\
\hline
\end{tabular}

Notes: Panel A reports regression results when weighting by mean ridership prior to Uber's existence (January 2005-August 2012). Panel B reports regression results when interacting the treatment variables with population density (rather than population). All other controls as in Table 3. Population density estimates come from Wilson et al. (2012) and are based on the 2010 Census and weighted by population at the census tract level to reflect the population density of the typical resident. Results are unchanged by using the unweighted population density. All other controls as in Table 3. Standard errors are reported in parentheses and clustered at the MSA level.

${ }^{*} p<.1 ; * * p<.05 ;{ }^{* * *} p<.01$ 
Table A.2: (continued)

\begin{tabular}{|c|c|c|c|c|c|c|c|c|c|c|c|c|}
\hline & \multicolumn{4}{|c|}{ Total } & \multicolumn{4}{|c|}{ Bus } & \multicolumn{4}{|c|}{ Rail } \\
\hline & \multicolumn{2}{|c|}{ Uber entry } & \multicolumn{2}{|c|}{ Uber penetration } & \multicolumn{2}{|c|}{ Uber entry } & \multicolumn{2}{|c|}{ Uber penetration } & \multicolumn{2}{|c|}{ Uber entry } & \multicolumn{2}{|c|}{ Uber penetration } \\
\hline & (1) & (2) & (3) & (4) & (5) & (6) & (7) & (8) & (9) & (10) & (11) & (12) \\
\hline \multicolumn{13}{|c|}{ Panel C: Leaving out New York City } \\
\hline UberX & $\begin{array}{r}-0.00272 \\
(0.0158)\end{array}$ & $\begin{array}{l}0.00471 \\
(0.0379)\end{array}$ & $\begin{array}{l}0.0133^{* *} \\
(0.00547)\end{array}$ & $\begin{array}{c}0.0107 \\
(0.00657)\end{array}$ & $\begin{array}{c}0.0185 \\
(0.0186)\end{array}$ & $\begin{array}{c}0.0257 \\
(0.0340)\end{array}$ & $\begin{array}{l}0.0143^{* * *} \\
(0.00478)\end{array}$ & $\begin{array}{c}0.00445 \\
(0.00619)\end{array}$ & $\begin{array}{l}-0.0325 \\
(0.0225)\end{array}$ & $\begin{array}{c}-0.0856^{*} \\
(0.0459)\end{array}$ & $\begin{array}{l}0.00215 \\
(0.0158)\end{array}$ & $\begin{array}{l}-0.0214 \\
(0.0235)\end{array}$ \\
\hline $\begin{array}{l}\text { Above median population } \\
\quad \times \text { UberX }\end{array}$ & & $\begin{array}{l}0.0613^{* *} \\
(0.0306)\end{array}$ & & $\begin{array}{l}0.0346^{* * *} \\
(0.00864)\end{array}$ & & $\begin{array}{c}0.0360 \\
(0.0307)\end{array}$ & & $\begin{array}{c}0.0305^{* * *} \\
(0.0106)\end{array}$ & & $\begin{array}{c}0.0346 \\
(0.0463)\end{array}$ & & $\begin{array}{c}0.0136 \\
(0.0185)\end{array}$ \\
\hline $\begin{array}{l}\text { Above median ridership } \\
\quad \times \text { UberX }\end{array}$ & & $\begin{array}{c}-0.0905^{* * *} \\
(0.0323)\end{array}$ & & $\begin{array}{c}-0.0376^{* * *} \\
(0.0105)\end{array}$ & & $\begin{array}{r}-0.0542^{* *} \\
(0.0274)\end{array}$ & & $\begin{array}{c}-0.0197^{*} \\
(0.0103)\end{array}$ & & $\begin{array}{c}0.0538 \\
(0.0435)\end{array}$ & & $\begin{array}{c}0.0198 \\
(0.0173)\end{array}$ \\
\hline Observations & 66,757 & 66,757 & 53,386 & 53,386 & 49,500 & 49,500 & 38,878 & 38,878 & 6,569 & 6,569 & 6,502 & 6,502 \\
\hline Clusters & 308 & 308 & 226 & 226 & 293 & 293 & 215 & 215 & 44 & 44 & 42 & 42 \\
\hline \multicolumn{13}{|c|}{ Panel D: No controls } \\
\hline UberX & $\begin{array}{c}0.0212 \\
(0.0189)\end{array}$ & $\begin{array}{c}0.0438 \\
(0.0518)\end{array}$ & $\begin{array}{l}0.0160^{* *} \\
(0.00655)\end{array}$ & $\begin{array}{c}0.00792 \\
(0.00895)\end{array}$ & $\begin{array}{c}0.0215 \\
(0.0211)\end{array}$ & $\begin{array}{l}0.00448 \\
(0.0542)\end{array}$ & $\begin{array}{c}0.0117^{*} \\
(0.00595)\end{array}$ & $\begin{array}{r}-0.000468 \\
(0.00881)\end{array}$ & $\begin{array}{l}-0.0518^{*} \\
(0.0273)\end{array}$ & $\begin{array}{l}-0.120^{*} \\
(0.0647)\end{array}$ & $\begin{array}{l}0.00779 \\
(0.0185)\end{array}$ & $\begin{array}{r}-0.00692 \\
(0.0290)\end{array}$ \\
\hline $\begin{array}{l}\text { Above median population } \\
\quad \times \text { UberX }\end{array}$ & & $\begin{array}{l}0.0872^{* *} \\
(0.0402)\end{array}$ & & $\begin{array}{c}0.0501^{* * *} \\
(0.0109)\end{array}$ & & $\begin{array}{l}0.101^{* *} \\
(0.0432)\end{array}$ & & $\begin{array}{c}0.0438^{* * *} \\
(0.0113)\end{array}$ & & $\begin{array}{c}0.0762 \\
(0.0773)\end{array}$ & & $\begin{array}{c}0.0206 \\
(0.0250)\end{array}$ \\
\hline $\begin{array}{l}\text { Above median ridership } \\
\quad \times \text { UberX }\end{array}$ & & $\begin{array}{c}-0.147^{* * *} \\
(0.0462)\end{array}$ & & $\begin{array}{c}-0.0515^{* * *} \\
(0.0135)\end{array}$ & & $\begin{array}{l}-0.105^{* *} \\
(0.0419)\end{array}$ & & $\begin{array}{c}-0.0363^{* * *} \\
(0.0136)\end{array}$ & & $\begin{array}{c}0.0185 \\
(0.0691)\end{array}$ & & $\begin{array}{r}-0.00578 \\
(0.0220)\end{array}$ \\
\hline Observations & 75,860 & 75,860 & 61,532 & 61,532 & 65,615 & 65,615 & 52,317 & 52,317 & 8,449 & 8,449 & 8,359 & 8,359 \\
\hline Clusters & 316 & 316 & 229 & 229 & 311 & 311 & 226 & 226 & 46 & 46 & 44 & 44 \\
\hline
\end{tabular}

Notes: Panel C reports results leaving out all observations from the New York City MSA, and has all other controls as in Table 3. Panel D reports results leaving out the controls, but still including the linear MSA time-trend and fixed effects for each month-year, transit agency, and transit agency-calendar month pairs. Standard errors are reported in parentheses and clustered at the MSA level. See notes for Table 3 for additional details.

${ }^{*} p<.1 ; * * p<.05 ;{ }^{* * *} p<.01$ 
Table A.3: Alternate methods of statistical inference for the effect of Uber on log public transit ridership

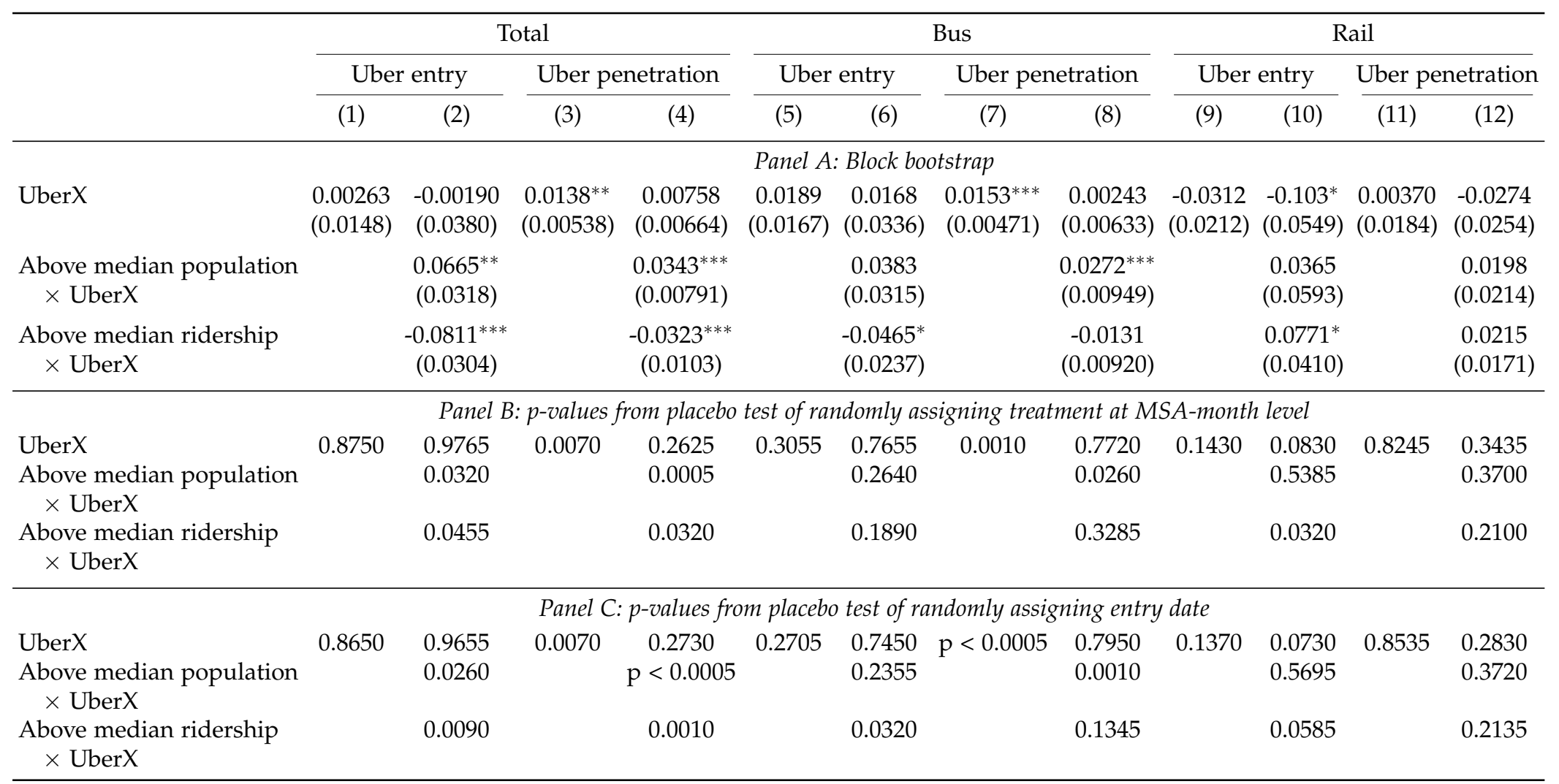

Notes: Panel A calculates standard errors using block bootstrapping at the MSA level (with two thousand draws), while Panels B and C report p-values from a placebo test. In Panel B we randomly re-assign the observed treatment variables at the MSA-month level. In Panel C we randomly assign which cities Uber enters and when. For the penetration data in Panel C, we assign treated cities a penetration history from an MSA which was actually treated and adjust the timing to match the placebo treatment date. For untreated cities, we randomly assign a penetration history from an MSA which was not treated. We then calculate $\mathrm{p}$-values by comparing the t-statistic from our main results to those generated by two thousand placebo treatments. All other controls as in Table 3.

${ }^{*} p<.1 ; * * p<.05 ; * * * p<.01$ 